\title{
Detailed flow, hydrometeor and lightning characteristics of an isolated thunderstorm during COPS
}

\author{
K. Schmidt ${ }^{1}$, M. Hagen ${ }^{1}$, H. Höller ${ }^{1}$, E. Richard ${ }^{2}$, and H. Volkert ${ }^{1}$ \\ ${ }^{1}$ Deutsches Zentrum für Luft- und Raumfahrt (DLR), Institut für Physik der Atmosphäre, Oberpfaffenhofen, Germany \\ ${ }^{2}$ Laboratoire d'Aérologie, CNRS and Université de Toulouse III, Toulouse, France
}

Correspondence to: K. Schmidt (kersten.schmidt@dlr.de)

Received: 2 March 2012 - Published in Atmos. Chem. Phys. Discuss.: 16 April 2012

Revised: 5 July 2012 - Accepted: 13 July 2012 - Published: 1 August 2012

\begin{abstract}
The three-hour life-cycle of the isolated thunderstorm on 15 July 2007 during the Convective and Orographically-induced Precipitation Study (COPS) is documented in detail, with a special emphasis on the rapid development and mature phases. Remote sensing techniques as 5min rapid scans from geostationary satellites, combined velocity retrievals from up to four Doppler-radars, the polarimetric determination of hydrometeors and spatio-temporal occurrences of lightning strokes are employed to arrive at a quantification of the physical parameters of this, during the COPS period, singular event.

Inner cloud flow fields are available from radar multiple Doppler analyses at four consecutive times separated by 15 min-intervals. They contain horizontal winds of around $15 \mathrm{~m} \mathrm{~s}^{-1}$ and updrafts exceeding $5 \mathrm{~m} \mathrm{~s}^{-1}$, the latter collocated with lightning strokes. Reflectivity and polarimetric data indicate the existence of hail at the $2 \mathrm{~km}$ level around 14:40. Furthermore, polarimetric and Doppler radar variables indicate intense hydrometeor variability and turbulence corresponding to an enhanced variance of the retrieved 3-D wind fields. Profiles of flow and hydrometeor statistics over the entire cloud volume provide reference data for high-resolution numerical weather prediction runs in research mode.

The study embarks from two movie-loops of geostationary satellite imagery (as Supplement), which provide an intuitive distinction of six phases making up the entire life-cycle of the thunderstorm. It concludes with a triple-image loop, juxtaposing a close-up of the cloud motion as seen by Meteosat, simulated brightness temperature (as a proxy for clouds seen by the infrared satellite channel), and a perspective view on the model generated system of cloud cells. The simulation suggests that several updrafts fed from a low level conver-
\end{abstract}

gence line eventually removed the convective inhibition and set deep convection in motion. A shear line in the radial velocity relative to the Feldberg radar site shows good agreement beween observation and simulation, whereas the onset location of deep convection exhibits a horizontal discrepancy of $15 \mathrm{~km}$. A quantitative schematic of the isolated thunderstorm synthesizes all retrieved characteristics.

\section{Introduction}

Thunderstorms constitute an archetype of a fierce meteorological event accompanied by a fleet of potential dangers, e.g. severe gusts, high precipitation rates, large hail, and lightning. Within thunderstorms the vertical motion - updrafts and downdrafts subsumed under the term convection - often attains similar magnitudes as the horizontal wind or advection, rather than remaining two orders of magnitude smaller as under ordinary circumstances. In mid-latitudes, thunderstorms are often connected to dynamically active frontal zones of cyclones or they develop in isolation when atmospheric conditions favour their initiation, especially on hot summer days. The latter category exhibits a typical life cycle, for which three phases can be distinguished (Cotton and Anthes, 1989, p. 456): the initiation of convection by surface heating and horizontal convergence at a variety of locations becomes marked by towering cumulus clouds; the mature stage sees the merger of several cumulus elements into a large convective system with the formation of various hydrometeors, the occurrence of lightning discharges compensating previous charge separations, and the onset of precipitation; during the dissipating phase downdrafts prevail in the 
storm's lower part and block convective energy being further fed into the storm.

The quantitative documentation of a thunderstorm's life cycle was among the objectives of the Convective and Orographically-induced Precipitation Study (COPS; Wulfmeyer et al., 2011), which had its field phase from June to August 2007 over an area in central Europe which covers the region of Vosges, Rhine valley and Black Forest in eastern France and south-western Germany. The provision of datasets concerning the airflow, the hydrometeor distribution and lightning locations with an appropriate spatial and temporal resolution complements previous surveys (e.g. Browning and Ludlam, 1962; Höller, 1994; Lang and Rutledge, 2002) and constitutes an important ingredient for the ongoing development of high resolution numerical weather prediction models and quantitative precipitation forecasts (e.g. Richard et al., 2011).

Multiple-Doppler-analyses integrate data from several Doppler-radars and reveal the flow components during the mature phase after the onset of precipitation, i.e. when sufficient backscattering particles are available. Additionally, independent polarization measurements in two perpendicular planes allow the discrimination of various hydrometeors. In a pioneering study, Wakimoto and Bringi (1988) mapped a highly dynamical thunderstorm and the induced microburst on 20 July 1986 over Alabama (USA), inter alia by superposing the visual external appearance of the cloud system (photos) with its internal reflectivity structure. Tuttle et al. (1989) extended the analysis to polarimetric parameters and comparisons with a two-dimensional cloud model. Frame et al. (2009) combine Doppler- and polarimetric analyses for a supercell thunderstorm on 23 May 2002 during the IHOP campaign, whereas Chong et al. (2000) systematically retrieved from dual-Doppler radar data orographically disturbed flows at the southern flank of the Alps during the special observing period of the Mesoscale Alpine Programme in autumn 1999 including an adequate determination of the vertical motion. Also Matejka and Barthels (1998) had investigated the accuracy of vertical motion obtained from radar measurements, while variational refinements of the retrieval technique are more recent (Shapiro et al., 2009; Lim and Sun, 2010). Dolan and Rutledge (2007) presented an integrative tool for the analysis and display of multivariate radar data. As its operational application in Europe is currently limited to special regions (Bousquet et al., 2008), dedicated experimental campaigns, like COPS, are still necessary for principal case studies.

Lightning strokes are among the most spectacular meteorological phenomena of local extent and, as a physical process, possess a long tradition of detailed investigation (e.g. Wilson, 1921). The sound produced by the sudden reversal of the previously attained charge separation by fast moving hydrometeors cannot be overheard and makes also in plain language a "thunderstorm" distinct from an ordinary storm. Specialized studies deal with correlations between flash rate, graupel volume, updraft volume and updraft mass flux (e.g. Kuhlman et al., 2006). Others relate observations of lightning rate to hydrometeor content (Fehr et al., 2005; Deierling et al., 2008) or to updraft motion (Deierling and Petersen, 2008).

During the three months of the COPS field phase it was only during intensive observation period (IOP) $8 \mathrm{~b}$ on 15 July 2007 that an isolated, strong and high reaching, though short-lived thunderstorm developed just east of the crest line of the Black Forest - much in contrast to the hopes of the large international team in the field that they can probe a number of such isolated as well as very pronounced systems, and to old popular wisdom about the peculiarity of the region ("... but a Black Forest thunderstorm is not an ordinary circumstance"; Jerome, 1900, p. 168). Let us first seek an overview of the overall development through a movie-loop obtained from satellite imagery.

Since the launch of the Meteosat Second Generation geostationary satellite series in 2004 with its multi-channel "spinning enhanced visible and infra-red imager" (SEVIRI; Aminou, 2002), the update rate of one image every $15 \mathrm{~min}$ in normal mode and every $5 \mathrm{~min}$ in rapid scan mode provides the opportunity to inspect in detail cloud motions as time-lapse movie-loops. From data of the experimental rapid scans executed during COPS, three channel overview images were produced on a stereographic weather-map-projection. The COPS area's circumference is dotted with $10^{\circ} \mathrm{E}$ as eastern boundary; it contains in its western half the Vosges and Black Forest mountains separated by south-north extending upper Rhine valley. Two loops are provided as Supplement to give an intuitive awareness of the horizontal dimensions and the duration of the thundercloud development as well as its relation to other cloud systems during 15 July 2007: (i) an overview for western and central Europe concatenating 145 images (movie1.mpg) between 06:00 and 18:00 (all times in UTC) with a nominal display speed of 14 frames per second (4,200-fold speed-up), and (ii) a close up for the wider COPS region consisting of 97 images between 10:00 and 18:00 (movie2.mpg) at half the speed ( $7 \mathrm{fps} ; 2,100$-fold speed up).

These are considered as the overall features of the event, which provide the frame for the detailed data analyses of this study: (i) well ahead of a frontal cloud band across France small cumulus clouds develop around 12:00 only over the mountains of the Vosges, the Black Forest and the Alps; (ii) the formation of a nearly contiguous, 100-km-long cloud line over the eastern slopes of the Black Forest by 13:00; (iii) the gradual enhancements of the cloud line's southern and northern portions until 14:00; (iv) the sudden vertical development at the middle location at 14:30, which induces a dark shadow to its east; (v) the formation of a wide and curved anvil around 15:00, and (vi) its detachment as well as north-eastern progression relative to a few remaining cumuli at low levels. 

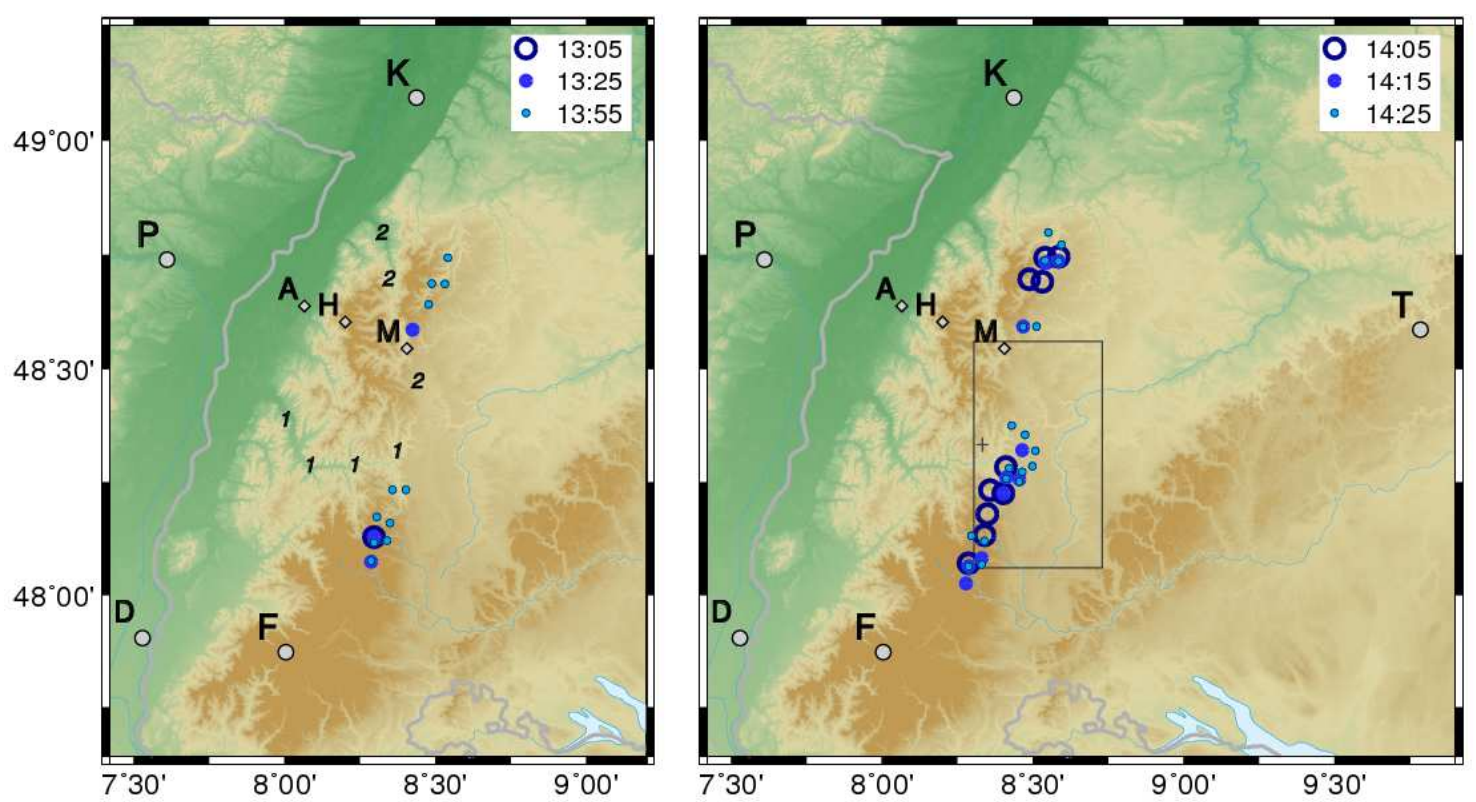

Fig. 1. Origin and north-easterly propagation of cool cloud tops $\left(10.8 \mu \mathrm{m}\right.$ brightness temperature below $\left.5^{\circ} \mathrm{C}\right)$ relative to the topography of the Black Forest during the $80 \mathrm{~min}$ period of the thunderstorm cumulus and early mature state. COPS supersites are marked by gray diamonds (A: Achern, H: Hornisgrinde, M: Murg-Valley), radar sites by circles (D: Doppler on wheels, F: Feldberg, P: Poldirad, K: Karlsruhe, T: Türkheim), course of rivers (1: Kinzig, 2: Murg). The rectangle indicates the area $\left(30 \times 55 \mathrm{~km}^{2}\right)$ of detailed multiple-Doppler analyses (“+” marks origin within Fig. 3).

With an entire lifetime of hardly more than three hours, the "golden thunderstorm" of COPS clearly lies close to the border of what can be hoped for the coming decades to be the spatio-temporal resolution of both multi-parameter and multiple-radar monitoring as well as reliable simulation of precipitation complexes in a quasi-operational mode. The aim of this study is to provide a documentation as complete as possible of the thunderstorms flow, hydrometeor and lightning characteristics with special emphasis on its rapid development and mature phase between 14:20 and 15:20. At the end the findings are to be combined to a conceptual picture of the event. A juxtaposition of the mid-level flow structures as inferred from the combined observations and as provided by a four-fold nested simulation with $500 \mathrm{~m}$ resolution points the direction to a series of sensitivity studies based on this exemplary event.

The paper is structured as follows: the single isolated "text-book case" of a thunderstorm during the COPS period induced several studies from different perspectives, which are reviewed in Sect. 2. Then the various data sources for our combined perspective are introduced (Sect. 3), followed by the description of the applied methods (Sect. 4). The evolving characteristics of the mature and decaying thunderstorm, regarding the combined determination of horizontal and vertical flow, hydrometeor distribution and lightning positions make the core of the investigation (Sect. 5). Section 6 discusses the findings and points to future applications of the results provided.

\section{Previous studies concerning IOP8b of COPS}

Following a categorization of trigger mechanisms for deep convection during COPS, IOP8b was classified as "locally initiated" by Kottmeier et al. (2008). On this day the atmosphere over central Europe was essentially cloud free and stably stratified over the COPS area. Radiosoundings in the COPS area indicated moderate convective available potential energy (CAPE) and relative high convective inhibition (CIN) values (Kalthoff et al., 2009). These observations, however, were not obtained in the vicinity to the developing thunderstorm. The convection initiation process was documented through a series of MSG satellite images (infrared and visible channels) and low elevation precipitation scans from Feldberg radar (Aoshima et al., 2008). A shear line was detected in the radial velocity field of the Feldberg radar and identified as a mechanism triggering the development of lowlevel clouds (Kalthoff et al., 2009). Behrendt et al. (2011) scanned for IOP8b the broad variety of in-situ and remote sensing data regarding convection initiation processes. Over the Rhine valley the depth of the inversion topped boundary layer did not exceed $1 \mathrm{~km}$, while it rose to more than $2 \mathrm{~km}$ by 11:30 at supersite $M$ (see Fig. 1 for geographical location). Here cloud bases were determined at $3 \mathrm{~km}$ above sea level after 13:00.

Besides observational studies, the isolated thunderstorm of IOP8b also attracted considerable interest of the mesoscale modelling community. Realistic simulations with 
the regional forecasting model COSMO-DE (at 2.8 and $1 \mathrm{~km}$ horizontal resolutions) resulted in a capturing of the convergence line, but a complete lack of deep convection. Detailed analyses revealed that the simulated convergenceinduced lifting was not strong enough to overcome CIN, even when CAPE attained values exceeding $2000 \mathrm{~J} \mathrm{~kg}^{-1}$ (Barthlott et al., 2010). In a following model-comparison study, no less than eight mesoscale models attempted to reproduce the thunderstorm in a case study setting, three of which produced sufficient updraft velocities to overcome the convective inhibition. But matters are more complex and contain many subtleties. The French Meso-NH model, for instance produced deep convection, but exhibited too high moisture contents compared to those retrieved from the water-vapour lidar LEANDRE (Barthlott et al., 2011). Sensitivity experiments including variations in the prescribed soil moisture content demonstrated how this seemingly remote quantity can indeed modulate the moisture supply of the atmospheric boundary layer significantly (Richard et al., 2011). Also, an entire ensemble of detailed hind-casts with a research version MetOffice's Unified Model only produced deep convection after manually adjusting the moisture content in the boundary layer closer to the non-routine COPS data. Moreover, the simulation of the deep convection appeared to depend strongly on the position of the mesoscale convergence line relative to the Black Forest topography (Hanley et al., 2011).

Considering the apparent difficulties to realistically simulate the quickly evolving and short life cycle of the IOP8bstorm with state-of-the-art mesoscale models, Kirshbaum (2011) conducted semi-idealized, two-dimensional numerical experiments in ensemble mode with a cloud-resolving model tailored for the explicit simulation of moist convection. They were inspired by the isolated COPS thunderstorm and initialized by generalized profiles obtained from the upstream radiosounding station Burnhaupt. On the lee side of a symmetric mountain of Black Forest dimensions the lowlevel environment, which was generally hostile to the development of deep convection, experienced a gradual removal of CIN and moistening through shallow cumuli. For some of the randomly varied background wind conditions a rapid succession of updrafts ejected by the convective core provided a favourable environment for subsequent updrafts which ascended up to the tropopause level.

The brief survey of previous studies clearly shows that a consistent combination of the available remote sensing perspectives during the developing, mature and decaying phases of the deep convection event is still lacking. These are provided here for a number of height levels and time intervals. Both numerical conceptions, the realistic NWP as well as the partly idealized cloud resolving models, need reference data with good spatial and temporal resolution.

\section{Data sources}

This study takes a detailed and combined view on the rapid development, mature and decay phases of the IOP8bthunderstorm. The key physical quantities are cloud top heights; horizontal winds and their vertical shear; vertical motion, especially pronounced cores of updraft and downdraft; hydrometeor types and concentrations; and positions of lightning strokes. In this section the different data sources are introduced.

\subsection{Spectral channels of SEVIRI on Meteosat}

As stated in the introduction, several channels of the SEVIRI instrument on the Meteosat Second Generation (MSG) satellite are used here (Schmetz et al., 2002). The images used for the movie-loops and displayed as parts of Figs. 4, 13 , and 15 are rgb-composited from the visible channels at $0.6 \mu \mathrm{m}$ (red), at $0.8 \mu \mathrm{m}$ (green), and the inverted infrared channel at $10.8 \mu \mathrm{m}$ (blue). All three have a nominal horizontal resolution of $3 \mathrm{~km}$. The image resolution is enhanced by adding the better resolved broad band high resolution visible channel (HRV with $1 \mathrm{~km}$ nominal resolution) to the former two, following the technique defined by Krebs (2006, p. 34). During COPS, the European Organisation for the Exploitation of Meteorological Satellites (EUMETSAT) operated the standby spacecraft Meteosat- 8 in experimental rapid scan mode with the intervals between scans reduced to $5 \mathrm{~min}$ (instead of $15 \mathrm{~min}$ for the full disc). The rapid scans are used here.

While the visible channels clearly map the horizontal extent of isolated clouds and movie-loops depict their advection, cloud top heights can be estimated from infrared radiances (Roberts and Rutledge, 2003). Established empirical relationships and thresholds in local timeseries with short update intervals allow to infer the vertical development of convective clouds. The drop below $0{ }^{\circ} \mathrm{C}$ of the brightness temperature derived from the $10.8 \mu \mathrm{m}$ radiances is related to vertically growing cumuli with ongoing glaciation, whereas an equality of brightness temperatures at $10.8 \mu \mathrm{m}$ and at $6.2 \mu \mathrm{m}$ indicates a cloud top at the tropopause (Mecikalski and Bedka, 2006). Following Mecikalski et al. (2010) four indicators are used to specify time and location of the onset of deep convection (see Table 1). The findings are crossvalidated with analogous deductions from radar measurements and lightning positions.

\subsection{Radar observations}

A weather radar (radio detection and ranging) emits microwave pulses and detects the small fraction of pulse energy which is backscattered to the antenna by hydrometeorological targets, e.g. raindrops, snowflakes, ice particles. Radars with Doppler-capability additionally measure the relative velocity of hydrometeors along the line of 
Table 1. Selected indicators for identifying convection initiation on 15th July 2007 by using MSG brightness temperatures ( $T_{\mathrm{B}}$ ) of different channels after criteria from Mecikalski and Bedka (2006).

\begin{tabular}{llc}
\hline Indicator & Criteria & Attained on 15 July by \\
\hline cloud depth & $T_{\mathrm{B}}(10.8 \mu \mathrm{m})<0^{\circ} \mathrm{C}$ & $14: 00 \mathrm{UTC}$ \\
cloud depth & $\Delta T_{\mathrm{B}}(6.2-10.8 \mu \mathrm{m})$ exceed $-30 \mathrm{~K}$ & $14: 10 \mathrm{UTC}$ \\
updraft strength & $T_{\mathrm{B}}$ rate $(10.8 \mu \mathrm{m})<4 \mathrm{~K} / 15 \mathrm{~min}$ & $14: 10 \mathrm{UTC}$ \\
updraft strength & $\Delta T_{\mathrm{B}}$ rate $(6.2-10.8 \mu \mathrm{m})>3 \mathrm{~K} / 15 \mathrm{~min}$ & $14: 10 \mathrm{UTC}$ \\
cloud-top glaciation & $T_{\mathrm{B}}(10.8)$ drop below $0{ }^{\circ} \mathrm{C}$ over $15 \mathrm{~min}$ & $14: 15 \mathrm{UTC}$ \\
\hline
\end{tabular}

Table 2. Specific properties of different radars during IOP8b; DWD comprises Feldberg and Türkheim.

\begin{tabular}{|c|c|c|c|c|c|}
\hline $\begin{array}{l}\text { radar/ } \\
\text { scan modus }\end{array}$ & $\mathrm{PRF}[\mathrm{Hz}]$ & $v_{\max }\left[\mathrm{m} \mathrm{s}^{-1}\right]$ & $r_{\max }[\mathrm{km}]$ & $\begin{array}{l}\text { range } \\
\text { step }[\mathrm{m}]\end{array}$ & $\begin{array}{l}\text { repetition } \\
\text { rate }[\mathrm{min}]\end{array}$ \\
\hline $\begin{array}{l}\text { DWD volume } \\
\text { downwards }\end{array}$ & $\begin{array}{l}\text { dual mode }(3: 2) \\
1200,800\end{array}$ & 32 & 125 & 1000 & 15 \\
\hline $\begin{array}{l}\text { DWD volume } \\
\text { upwards }\end{array}$ & 500 & 6.7 & 300 & 1000 & 15 \\
\hline $\begin{array}{l}\text { DWD } \\
\text { precipitation }\end{array}$ & 600 & 8.0 & 250 & 1000 & 5 \\
\hline Karlsruhe & $\begin{array}{l}\text { dual mode }(4: 3) \\
1153,864\end{array}$ & 45 & 120 & 500 & 10 \\
\hline DoW near & 2000 & 15.88 & 51 & 150 & $\sim 3$ \\
\hline DoW far & 1000 & 7.92 & 144 & 240 & $\sim 3$ \\
\hline Poldirad & 1150 & 15.67 & 130 & 300 & 10 \\
\hline
\end{tabular}

the radar pulse. An overview of modern weather radar applications is given by Meischner (2003). In this study we use data of five radars, namely two Doppler-radars of Deutscher Wetterdienst (DWD) at Feldberg and Türkheim, the Dopplerradar at the Karlsruhe Institute of Technology (KIT), the truck-mounted Doppler-radar on wheels (DoW) positioned at Fessenheim on 15 July, and the polarimetric Doppler radar (Poldirad) of DLR, which was deployed at Waltenheim during the entire COPS period. DoW operates in the X-band frequency band, the other four in the further reaching $\mathrm{C}$ band. A number of installation dependent radar parameters, as range step, pulse repetition frequency (PRF), and single or dual PRF-operation mode are given in Table 2 along with derived quantities as maximum range $\left(r_{\max }\right)$ and the highest unambiguous radial velocity $\left(v_{\max }\right)$. Details of the multipleDoppler analysis, which combines data from several radars, are given in Sect. 4.

The DWD-radars at Feldberg and Türkheim are operated routinely in two different scan strategies: a precipitation scan at low elevation $\left(0.8^{\circ}\right)$ every $5 \mathrm{~min}$ and a full volume scan every $15 \mathrm{~min}$. The latter mainly includes 18 different elevations downwards from $37^{\circ}$ to $0.5^{\circ}$ with a better velocity resolution but shorter maximal range, while five addi- tional scans upward from 0.5 to $4.5^{\circ}$ are obtained with larger range, but lower velocity resolution (cf. Table 2). Radar data from Karlsruhe are available from the CERA database (http://cera-www.dkrz.de) every 10 min containing 13 elevations in ascending order. Poldirad repeated regular scans every $10 \mathrm{~min}$ but only at 3 elevations $\left(1^{\circ}, 2^{\circ}, 20^{\circ}\right)$. They are augmented by high resolving range height indicator (RHI) scans as well as by plan position indicator (PPI) sector scans with more than three elevations.

The mentioned observation details indicate that the consistent scanning of the quickly evolving deep convection event of short duration is (i) an extra challenge during the fixed routine schedule of DWD, and (ii) a sort of reactivity test for research radar operators who work long hours in the field for weeks. From 14:43 several series of RHI-slices moving with the strongest cell were undertaken. The DOW position from the storm proved to be beyond the range of near-field operation; from 14:30 to 14:47 three far-field scans with low $v_{\max }$ were undertaken.

The derivation of a consistent spatio-temporal allocation of unambiguous Doppler-observations forms the core of this study. Data from the three radars Feldberg, Türkheim and Karlsruhe are used for a series of triple-Doppler analyses at 
Table 3. Scan time intervals for the radars of the triple-Doppler analysis.

\begin{tabular}{cccc}
\hline Feldberg & Türkheim & Karlsruhe & analysis time \\
\hline $14: 30-14: 37$ & $14: 30-14: 37$ & $14: 30-14: 34$ & $14: 35$ \\
$14: 45-14: 52$ & $14: 45-14: 52$ & $14: 50-14: 54$ & $14: 50$ \\
$15: 00-15: 07$ & $15: 00-15: 07$ & $15: 00-15: 04$ & $15: 05$ \\
$15: 15-15: 22$ & $15: 15-15: 22$ & $15: 20-15: 24$ & $15: 20$ \\
\hline
\end{tabular}

15 min intervals (Table 3). Interpolation details are given in Sect. 4. Observations from Poldirad and DoW are used for cross-checks at intermediate times.

\subsection{Lightning location}

The location and time of lightning discharges is obtained from the European Lightning detection Network (LINET), which is in operation since 2004. Lightning is registered when the same electromagnetic pulse is observed at a minimum of four sensors of the network, which covers central Europe with an average displacement of $100 \mathrm{~km}$. Four additional sensors were installed in the COPS region for the duration of the campaign. Source locations can be determined with an accuracy of $50 \mathrm{~m}$. LINET discriminates cloudto-ground lightning from intra-cloud lightning and provides an estimates of the emission height for intra-cloud events. All technical features of LINET and comparisons with other lightning detection systems are described in Betz et al. (2004) and Schmidt et al. (2005).

Compared with satellite or radar measurements, the temporal and spatial resolutions of lightning observations are accurate indeed. In this study lightning locations are used as an indirect indicator for, e.g., updraft strength, turbulence or hydrometeor types, in particular during the early mature state of the thunderstorm and within the strongest updrafts.

\section{Radar retrieval methods}

Data from five radars with differences in wavelength, detection capabilities and scanning patterns were used in a coherent fashion in order to obtain a consistent determination of the storm's transient three-dimensional flow characteristics and hydrometeor content. Up to four C-band radars were combined for multiple Doppler-syntheses, while some scans obtained by the X-band DoW were used for consistency checks. Here we document how the flow characteristics were retrieved for an appropriate spatio-temporal grid and how hydrometeor content was determined from polarimetric measurements obtained by Poldirad.

\subsection{Doppler-wind retrievals}

Observational radar datasets (except from Poldirad) were obtained from the COPS archives at CERA and converted to a common format. As region of special interest, a Cartesian grid was defined with its origin at $48.3329^{\circ} \mathrm{N}$ and $8.3335^{\circ} \mathrm{E}$ (Fig. 1, right panel). This point coincides with the $70 \mathrm{~km}$ distance from Poldirad at the $130^{\circ}$ azimuth. The size of the retrieval domain has an horizontal extent of $55 \mathrm{~km} \times 30 \mathrm{~km}$ and a height of $14 \mathrm{~km}$. Distances of the grid points to the four Cband radars range from 25 to $135 \mathrm{~km}$.

The synthesis of multiple-Doppler winds is achieved by the CEDRIC software package (Miller and Fredrick, 1998) in close combination with the mapping programme REORDER (Oye and Case, 1995), both developed at NCAR with a special emphasis on observations from field experiments (Mohr et al., 1986). After systematic tests, a constant grid size of $0.5 \mathrm{~km}$ was chosen in all three spatial dimensions. Subsequent applications of REORDER map the radial radar velocities from spherical coordinates onto the Cartesian grid, separately for each of the radars with grid point dependent radii of influence in the Cressman-type interpolation scheme. These independent observations are synthesized by CEDRIC to obtain consistent Doppler-winds in all altitude levels. An unfolding of radial velocities was not necessary, as the Nyquist-velocity proved to be sufficiently large (Table 2). Standard procedures were applied for data filling and horizontal smoothing.

To account for the fast development and the progression of the disturbed wind field within the storm, the scanning schedules of the radars at the different elevations were observed as well as the background wind profile from the 14:00 sounding from Hornisgrinde. Radial velocities got adjusted for each radar site and iteratively underwent the REORDERCEDRIC-sequence until consistent in-cloud flow fields were determined at four independent nominal observing times separated by $15 \mathrm{~min}(14: 35,14: 50,15: 05,15: 20)$.

Finally, the vertical wind $w$ was determined by a vertical integration of the continuity equation using a variational method. Following the approach of Chong and Testud (1983), a variance of vertical velocity was specified at the upper and lower boundaries. Technically, this was realized within CEDRIC via the parameter FRACT inside the command INTEGR (Miller and Fredrick, 1998). Systematic variations regarding grid resolution, setting of filter parameters and details in the prescription of the boundary conditions proved the vertical velocities to be robust, particularly at mid-levels.

For all grid points an average reflectivity field was obtained, taking into account differing observations from the different radars. For the statistical sampling of grid points and the fine-scale display of the results, two horizontal masks were determined. The cloud masks contain all points with average reflectivity above $0 \mathrm{dBZ}$, while the updraft mask marks region outside of the cloud edge, but with vertical velocity exceeding $2 \mathrm{~m} \mathrm{~s}^{-1}$. 


\subsection{Hydrometeor retrievals}

Beside ordinary radar reflectivity and Doppler-quantities as radial velocity and spectral width, the polarimetric quantities obtained by Poldirad during COPS allow estimates regarding the hydrometeor type in categories as rain, snow, graupel and hail. In this study the linear polarization parameters differential reflectivity (ZDR) and linear depolarization ratio (LDR) are used in five adjacent cross-sections (RHIs) at 2 degree azimuth-intervals moving with the strongest cell of the thunderstorm.

ZDR is used to infer the particle shape, i.e. the ratio of mean upward to sidewards extent of the particles within a sampling volume of about $1 \mathrm{~km}^{3}$. For radar pulses emitted with alternating horizontal and vertical planes of polarization, ZDR is defined as the ten-fold logarithmic ratio of the return signals with the same orientation as the emitted pulses $\left(\mathrm{ZDR}=10 \log \left(Z_{\mathrm{H}} / Z_{\mathrm{V}}\right)\right)$. Spherical particles as small raindrops produce $Z D R$ values near zero, while large raindrops induce larger horizontal than vertical reflectivity and, thus, $Z D R>0$. The typical orientation and fall characteristics of ice particles induce ZDR values near zero or below. A combination of ZDR and ordinary reflectivity, termed differential hail signal (HDR; Aydin et al., 1986) is used to infer the presence of hail below the melting layer. Above the melting layer, only HDR $>30 \mathrm{~dB}$ serves as an indicator for hail. For pulses emitted with horizontal polarization the linear depolarization ratio (LDR) is defined as the tenfold logarithmic ratio of the vertical or cross-polar return to the horizontal or co-polar return $\left(\mathrm{LDR}=10 \log \left(Z_{\mathrm{HV}} / Z_{\mathrm{HH}}\right)\right.$ ). LDR is typically found to be more sensitive to hydrometeor variability within the measuring volume than ZDR. LDR tends to be very small for sampling volumes composed of only rain or ice particles. Its value increases when melting snow, water coated hail or graupel are within the volume. Therefore it serves as an indicator for ice above the melting layer.

Höller et al. (1994) provided a semi-empirical scheme for the classification of hyrometeors solely based on ZDR and LDR measurements, containing different classes of rain (small and large drops), ices particles (snow, graupel, hail) as well as mixed-phase constituents. For the short-lived summer thunderstorm under investigation, the scheme is applied here in a compact version, which just distinguishes rain, snow, graupel and hail as distinct classes. Furthermore by using Doppler spectral width, regions of enhanced turbulence can be identified.

\section{Detailed flow, hydrometeor and lightning characteristics}

After data and methods have been introduced, we present the observational findings of the thunderstorm's characteristics in combination. The documentation of the spatio-temporal development is followed by a description of flow characteris- tics and dynamical features including lightning activity. After analyzing the evolution of hydrometeor distribution during the storm, the observation results are juxtaposed to comparably resolved hindcasts of a numerical weather prediction model.

\subsection{Location and vertical development of convection}

Brightness temperatures from the $10.8 \mu \mathrm{m}$-infrared-channel of Meteosat are used to identify developing cumuli (Siewert et al., 2010). The pixel-wise, parallax-corrected locations of cloud formation $\left(\mathrm{BT}<5^{\circ} \mathrm{C}\right)$ relative to the Black Forest topography are given in Fig. 1 for six times during the 80-minperiod before the rapid development. Whereas a first ground based photo of a small cloud was reported for 11:15 UTC (Kalthoff et al., 2009), the first $3 \mathrm{~km}$ by $3 \mathrm{~km}$ SEVIRI pixel fell below the threshold at 13:05 over the northernmost extent of the southern Black Forest. 20 min later significant cumulus development also started above the high terrain to the east of the Murg valley in the northern Black Forest. These positions coincide with the previously documented line of low-level convergence (Kalthoff et al., 2009; Behrendt et al., 2011). A further $30 \mathrm{~min}$ later the development areas moved towards NNE covering more pixels. At 14:05 cumulus generation also started above the elevated saddle area, which separates the higher terrain of southern and northern Black Forest and lies directly to the east of the deep incision of the Kinzig valley. The gradual movement of "cool-BT-pixels" motivated the definition of the region of special interest for the multipleDoppler syntheses (box in the right panel of Fig. 1).

Time series of different overall characteristics of the passive $(10.8 \mu \mathrm{m}$-channel) and active (radar reflectivity) remote sensing information are combined in Fig. 2 in order to check the consistency of the data sources and to obtain estimates for rapid vertical development. Between 14:00 and 14:40 the minimum brightness temperature in this region dropped from $0^{\circ} \mathrm{C}$ to below $-50^{\circ} \mathrm{C}$, equivalent to cloud tops growing from 4 to $12 \mathrm{~km}$ (assuming a wet adiabatic lapse rate). The independent cloud top estimates from four radars agree well until 14:40. Later the thunderstorm's anvil, consisting of small ice particles, keeps its brightness temperature (and height of $12 \mathrm{~km}$ ) in the satellite data, while the radar-detectable clouds tops decrease to about $10 \mathrm{~km}$. The vanishing difference of the brightness temperatures from water vapour and infrared channels $(6.2-10.8 \mu \mathrm{m})$ indicates that the cloud top reaches the tropopause region (sounding data at 11:00 exhibit a tropopause just below $13 \mathrm{~km}$; Kalthoff et al., 2009). This proxy for fully developed deep convection (Mecikalski et al., 2010) is attained from 14:40 onwards (Fig. 2, lower panel). After 14:30 maximum reflectivity values from Poldirad exceed $40 \mathrm{dBZ}$, while lightning strokes were recorded during the 11 min period between 14:34 and 14:45.

Putting these overall indicators together, we set the begin of rapid development at 14:20. From the temporal gradient of cloud top height $(\Delta z / \Delta t=(11-8 \mathrm{~km}) /(14: 30-14: 25))$ the 


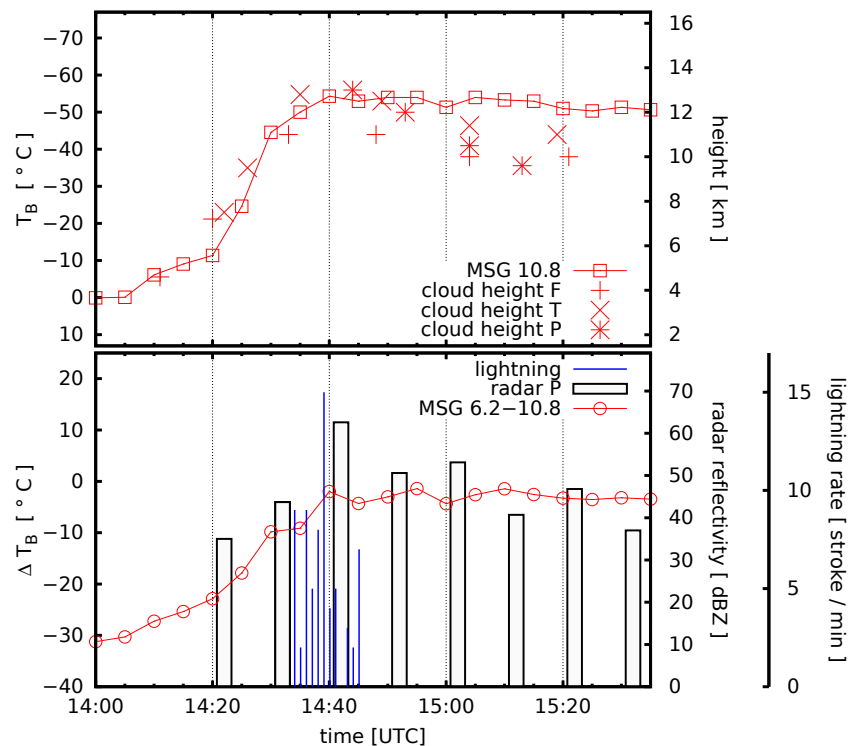

Fig. 2. Temporal evolution of cloud system characteristics derived from remote sensing instruments. Upper panel: minimum brightness temperature of IR channel $(10.8 \mu \mathrm{m})$ with corresponding cloud top height (assuming wet adiabatic lapse rate), and estimated cloud top heights from PPI scans of 3 radars (F: Feldberg, T: Türkheim, P: Poldirad). Lower panel: difference between minimum brightness temperatures of WV $(6.2 \mu \mathrm{m})$ and IR $(10.8 \mu \mathrm{m})$ channels, maximum radar reflectivity measured by Poldirad (at $2^{\circ}$ elevation), and lightning rate detected by LINET.

vertical motion of the cloud top is estimated as $10 \mathrm{~m} \mathrm{~s}^{-1}$. Already by 14:35 the thunderstorm attained its mature phase.

\subsection{Three-dimensional flow within the mature storm}

Triple-Doppler syntheses of the Feldberg, Karlsruhe and Türkheim radar-data provide a closer inspection of the flow within the mature storm at $15 \mathrm{~min}$ intervals. Figure 3 allows for the 5-km-level a compact depiction of the storm's extent (regions with dense arrows), its horizontal structure of two moving reflectivity cores, the highly perturbed inner-cloud horizontal motion and the patterns of updrafts and downdrafts. At 14:35 a strong updraft core $\left(w_{\max }=10.5 \mathrm{~m} \mathrm{~s}^{-1}\right)$ coincided with maximum reflectivity in the southern part of the northern cell (position: $(x, y)=(15 \mathrm{~km},-10 \mathrm{~km})$ ). It is there where the horizontal flow directions deviated most from the general motion towards NNE. A second, smaller updraft was situated at the cell's northern flank. At 14:50 the low reflectivity core at the southern edge of the box had intensified, while the northern cell had grown in extent in a north-easterly direction. Areas of downward motion (blue tones) increased, while upward motion is sustained at the cells southern flank. At 15:05 there were still two separate reflectivity cells which perturbed the horizontal flow considerably. The cloud-mask region, where high-resolution flow determination is meaningful, filled the box along its $60 \mathrm{~km}$ long diagonal. Patches of upward and downward motions alternated. By 15:20 the north-easterly progression had continued, reflectivity cells got united with shrinking extent. The densely resolved flow appeared less perturbed, except within the downdraft at the southern flank of the system. Since 14:50 the decay of the storm was in progress.

In order to obtain a clearer appreciation of the strongest cell's rapid development, a composite of a rectified lateral photograph, lightning locations and synthesized radar parameters in the photographer's perspective is given in Fig. 4, augmented by the plan view of three MSG rapid scans at 5 minintervals. The photograph stems from a series taken from the Poldirad site, some $80 \mathrm{~km}$ away from the cloud. The axes of azimuth and elevation angles were uniquely determined by recovering the distinct silhouette of the Black Forest from this location in a high-resolution topographic dataset. The vertical extent of the multiple radar reflectivity contours at 14:35 (black lines) coincide with the photo of $14: 42$, while the cloud's progression to the north-east (i.e. to the left) is evident from the $2^{\circ}$ difference at the trailing (right) side. Otherwise, the high lateral gradient of reflectivity at mid-levels is consistent with the visually distinct cloud boundary composed of the convex elements of a cumulus congestus at $132^{\circ}$ azimuth. The cloud tail around $2.5^{\circ}$ elevation and $134^{\circ}$ azimuth remains stationary through several photographs (not displayed). The area of imminent vertical growth at $3^{\circ}$ elevation and $133^{\circ}$ azimuth is too small to be properly resolved in the multiple-Doppler analysis.

The azimuth band between $126^{\circ}$ and $132^{\circ}$ contains the region of most active development, where updrafts exceeding $11 \mathrm{~m} \mathrm{~s}^{-1}$ and lightning strokes, both in-cloud and cloud-toground ones, are collocated. The highest part of the cloud (elevation $>10^{\circ}$ at $128^{\circ}$ azimuth) is situated directly above the strongest updraft. Areas of downward motion lie mostly at the edge of the cloud. Note that all retrieved parameters are sampled along the lines of sight (i.e. into the cloud); therefore upward and downward motion appear to overlap in places. The three small satellite scenes at $5 \mathrm{~min}$ intervals put the lateral view in perspective: (i) the viewing angle of $18^{\circ}$ merely covers a small part of the entire elongated cloud system; (ii) the shadow throwing anvil dominates the satellite perspective from some $36000 \mathrm{~km}$, while the side view from about $80 \mathrm{~km}$ reveals separated cumulus complexes. The (not corrected) parallax of the viewing geometry places the elevated anvil too far north relative to its shadow on the ground. Therefore (geostationary) satellite imagery is most valuable for qualitative estimates of a convective-cloud-system's extent and it progression with time, while more a precise assessment of timing and location necessitates remote sensing equipment in closer proximity.

Following the spatial depiction of the radar-retrieved flow structure and a plausibility check against the visible appearance of the thunder-cloud, a statistical analysis of the flow's vertical profile provides additional information. Four consecutive profiles of horizontal wind speed and direction 


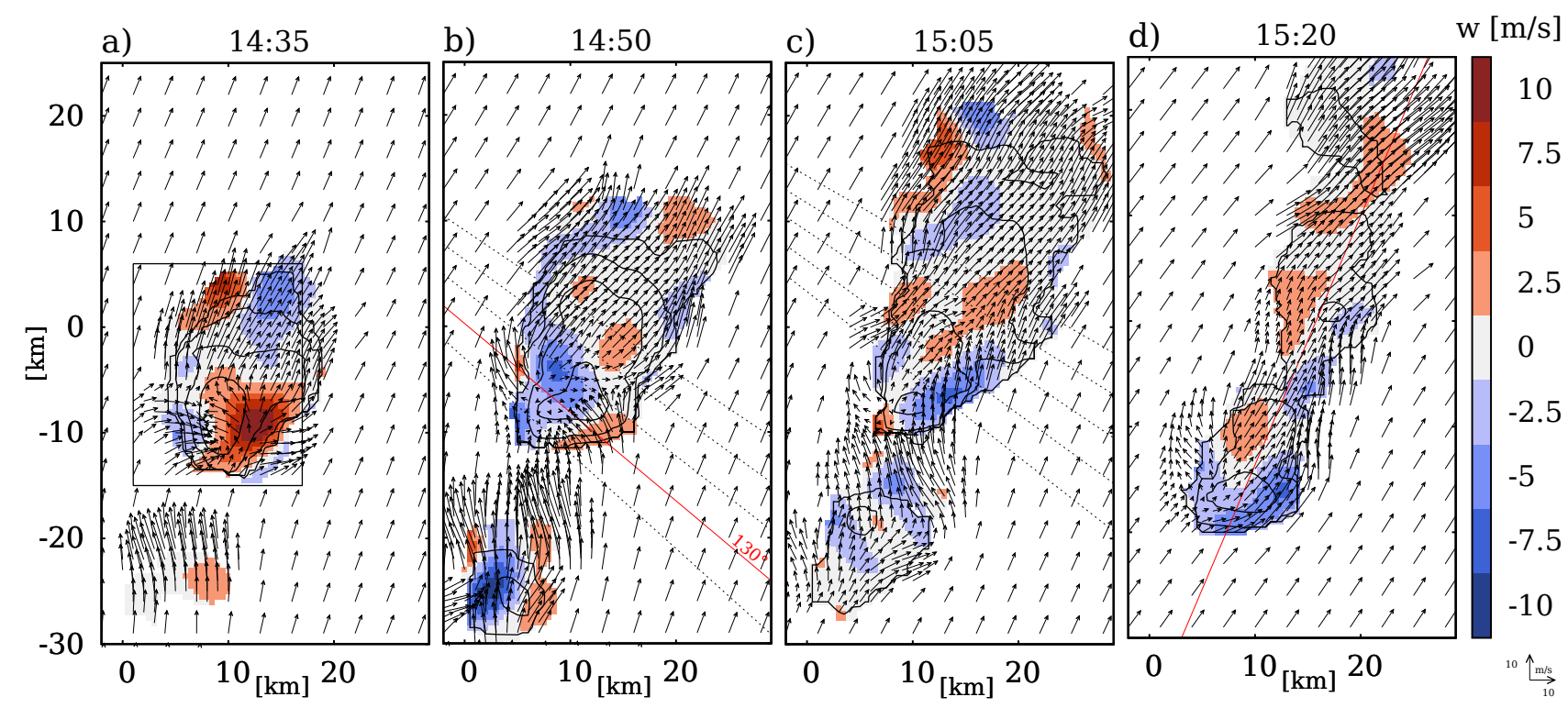

Fig. 3. Mid-cloud flow structures from triple-Doppler analyses at $5 \mathrm{~km}$ (MSL) in 15 min intervals: horizontal wind vectors every $3 \mathrm{~km}$ outside and $1 \mathrm{~km}$ inside or near the cloud structure, colour coded vertical velocity (positive values for upward motion), and averaged reflectivity isolines $(10 \mathrm{dBZ}$ intervals, starting from $10 \mathrm{dBZ})$. The origin $(0,0)$ is located at $48.3329^{\circ}$ north, $8.3335^{\circ}$ east. Lines in (b) and (c) mark available azimuth angles for Poldirad RHI scans from 14:43 to 14:53, and 15:03 to 15:23, respectively. Red Lines in (b) and (d) denote vertical cross sections in Figs. 10 and 13, respectively; the rectangle in (a) denotes the edge of Fig. 9.
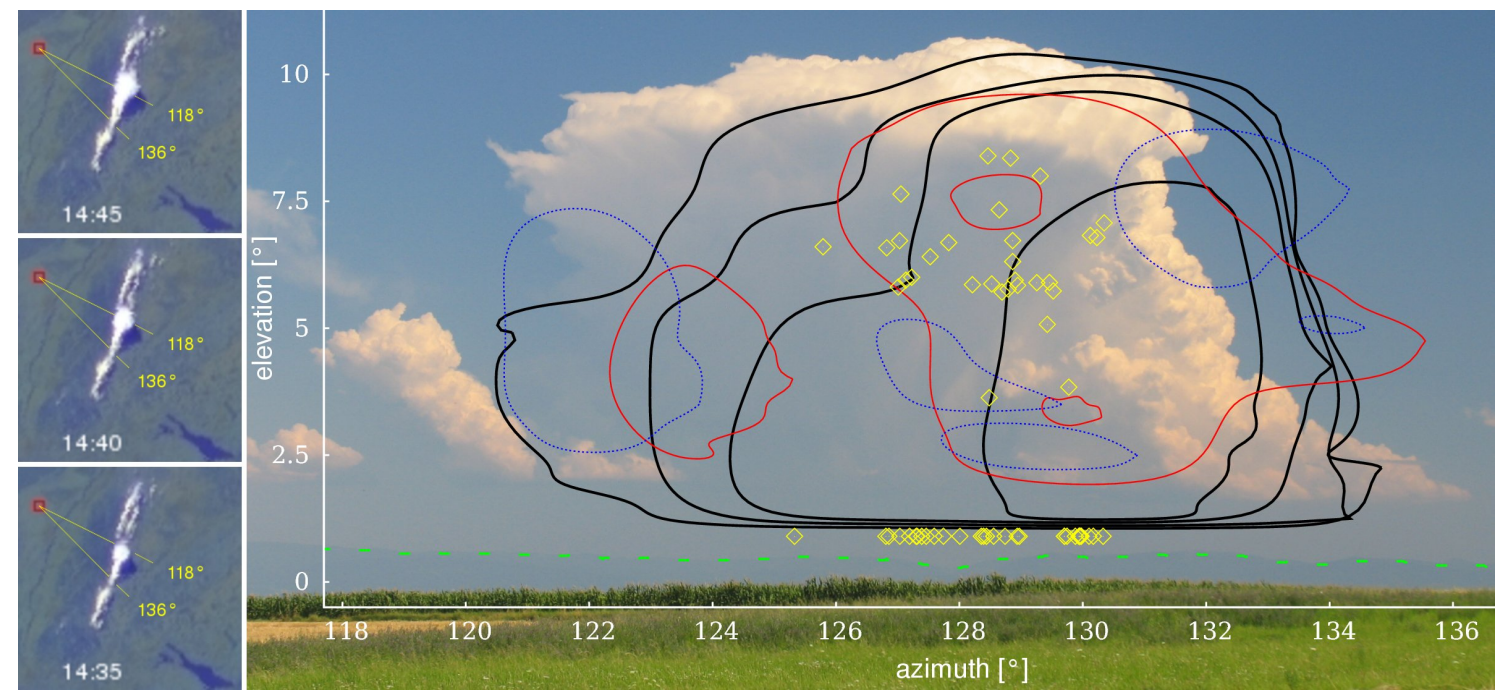

Fig. 4. Visual appearance of the early mature state cumulonimbus from different perspectives in combination with various retrieved physical parameters. Right: levelled photograph from Poldirad site at 14:42 UTC (Black Forest silhouette recovered from digital elevation model: green line) with maximum values along lines of sight for reflectivity (black contours from $0 \mathrm{dBZ}$ with $10 \mathrm{dBZ}$ intervals) and vertical motion (updraft: red contours at 4, $11 \mathrm{~m} \mathrm{~s}^{-1}$; downdraft: blue dotted line at $-4 \mathrm{~m} \mathrm{~s}^{-1}$ ) from triple-Doppler analysis at 14:35; positions of intra-cloud and ground lightning until 14:45 are indicated by yellow diamonds. Left: position of cloud system with shadow as seen from Meteosat for three consecutive times relative to Poldirad (red square) and $18^{\circ}$-wide-viewing angle.

are determined as mean and standard deviation taking in account all cloud-mask points of the triple-Doppler analyses (Fig. 5) and juxtaposed to the 14:00 sounding at Hornisgrinde supersite ( $\mathrm{H}$ in Fig. 1). The averaged profiles were smoother than the sounding at a single (and drifting) loca- tion, while the overall height dependence was consistent with a rather uniform direction between 4 and $12 \mathrm{~km}$ (southerly from $200^{\circ}$ ) and gradually increasing with height from below $5 \mathrm{~m} \mathrm{~s}^{-1}$ (at $2 \mathrm{~km}$ ) to $15 \mathrm{~m} \mathrm{~s}^{-1}$ (at $12 \mathrm{~km}$ ). At 14:35 the fluctuations were largest at the highest levels, while the standard 


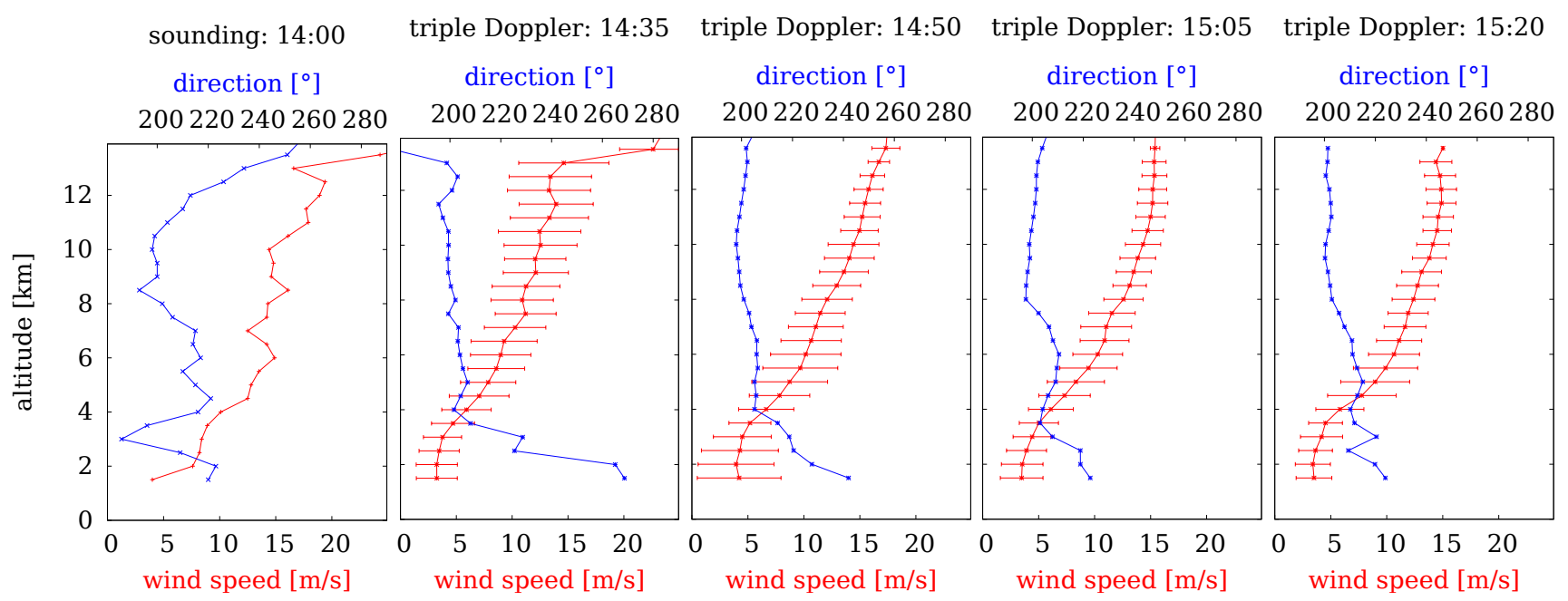

Fig. 5. Temporal development of profiles of horizontal wind speed (red) and direction (blue) measured by sounding at supersite "Hornisgrinde" at 14:00 and retrieved mean values from triple-Doppler analyses. Error bars display the standard deviation of mean wind speed for triple-Doppler retrievals.
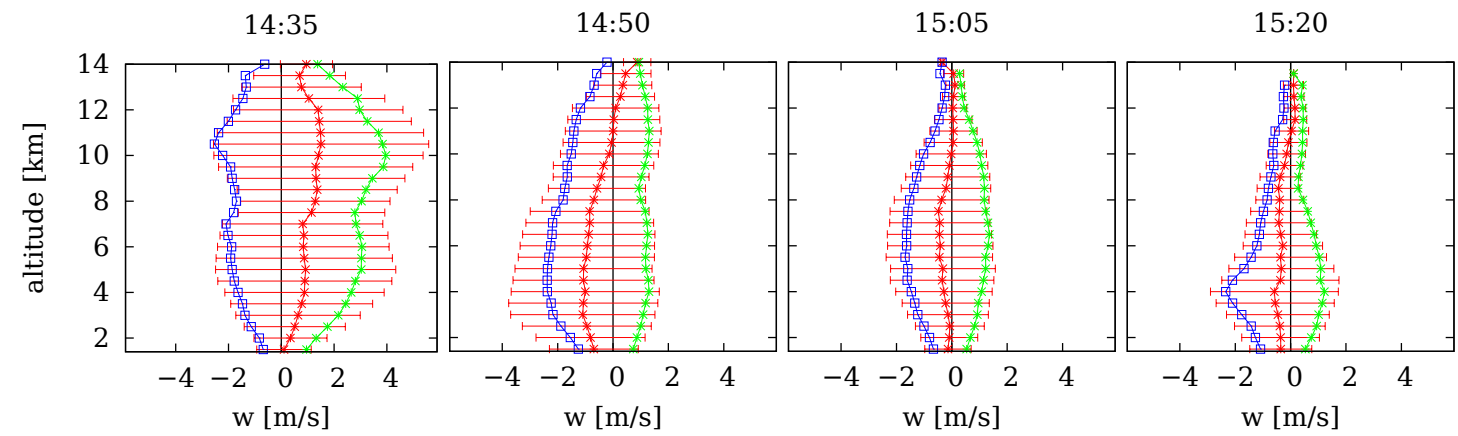

Fig. 6. Temporal development of profile statistics of mean vertical velocity $(w)$ from triple-Doppler analyses: average of all values with standard deviation (red), average of updrafts (green), and of downdrafts (blue).

deviation diminished somewhat at the later instants when its largest values were found at mid-levels. Meaningful retrievals were only possible above $1.7 \mathrm{~km}$ where radar beams are unblocked by orography from all radar-sites. At 14:35 the mean wind shear below the $6 \mathrm{~km}$ level amounted to about $8 \mathrm{~m} \mathrm{~s}^{-1}$, which is consistent to the empirical threshold value which distinguishes single-cell from multi-cell thunderstorms (Markowski and Richardson, 2010, p. 206). Please note that statistics within the clouds are a form of conditional sampling which cannot be expected to be representative for the background flow. Analogous statistics for the vertical wind are assembled in Fig. 6, separately sampled over all valid data points (red), as well as over those exhibiting rising (green) or sinking (blue) motion. At 14:35 mean updrafts were more intense than downdrafts and exceed $2 \mathrm{~m} \mathrm{~s}^{-1}$ at all levels with standard deviations around and above $4 \mathrm{~m} \mathrm{~s}^{-1}$, which appears to be consistent with the storm's most active phase. During the following $45 \mathrm{~min}$ the downdraft-strength was exceeding the updraft-strength and the variability shrinks from the top. At 15:20 vertical velocities exceeding $2 \mathrm{~m} \mathrm{~s}^{-1}$ were confined to the $4 \mathrm{~km}$ level, while mean vertical velocities were found to be about two orders of magnitude smaller than the horizontal ones $\left(0.1 \mathrm{~m} \mathrm{~s}^{-1}\right.$ versus $10 \mathrm{~m} \mathrm{~s}^{-1}$ ). The distinct convective event was about to be over.

\subsection{Uncertainty of wind retrieval results due to small scale variability}

For evaluating the uncertainty of the derived threedimensional wind field, the measured radial velocities were compared with retrieved values for each radar and summarized as a root mean square (rms) deviation. From 14:50 onwards all rms-values are within a range of 0.5 and $2.5 \mathrm{~m} \mathrm{~s}^{-1}$, indicating a compliance of the retrieved wind vectors with the original measured radial components (Fig. 7). For the early mature phase at 14:35, the rms-values are significantly enhanced. They are in agreement with the trend of horizontal and vertical profile statistics (in Figs. 5 and 6) and appear plausible because of more vigorous dynamics during 


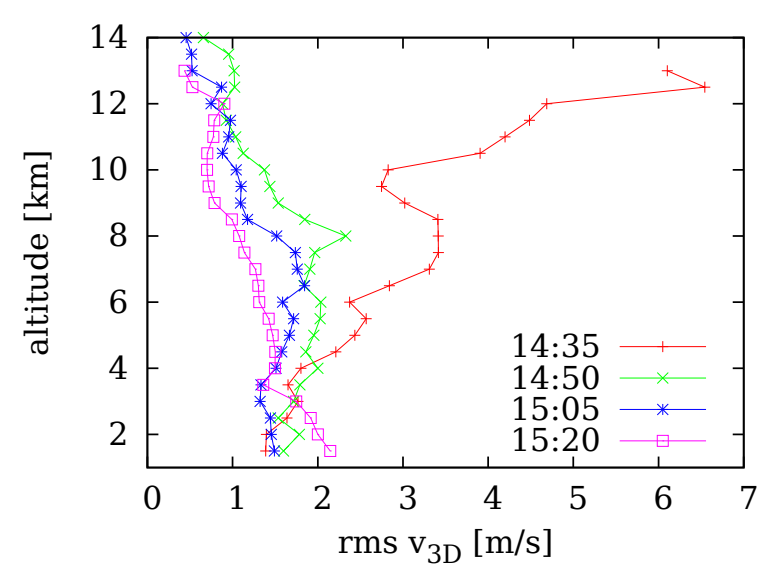

Fig. 7. Consistency check for triple-Doppler results expressed by root mean square deviation comparing observed radial velocities from each individual radar with retrieved values. For the calculation, elevation, azimuth, and location of radars for all four retrieval runs were taken into account (see Table 3).

this phase. For instance, the local rms-maximum at $8 \mathrm{~km}$ altitude amounts to $3.5 \mathrm{~m} \mathrm{~s}^{-1}$ at $14: 35$ and decreases to 2.5 at 14:50. Furthermore, at 14:35, the rms-trend for altitudes higher than $10 \mathrm{~km}$ increases roughly linearly with height, attaining a value of $6.5 \mathrm{~m} \mathrm{~s}^{-1}$ at the presumed cloud-top height of $12 \mathrm{~km}$. Apparently, the enhanced rms-values are induced by the rapid growth of the cloud during the 15-min-retrievalinterval. A shorter radar observation cycle would presumable provide retrievals with smaller rms-deviations during periods of rapid developments.

To investigate the effect of strong dynamic and turbulence in more detail, special fourfold-Doppler retrievals were performed, including RHI scans of Poldirad, and compared with additional radar-parameters available from Poldirad. A reference time was selected between 14:35 and 14:50, when the cloud was fully developed. The first high-resolution RHIscans are available at 14:43; their positions are marked as lines in Fig. 3b. For the current retrieval these data are blended with the radar data of Feldberg and Türkheim taken during the 14:45-to-14:52-interval and with the Karlsruhe data from 14:40 to 14:44. Most revealing is a section through the region of maximum reflectivity (red line in Fig. 3b). Details are juxtaposed in Fig. 8. First, the RHI-reflectivity is overlaid with retrieved winds along the section with updrafts $\left(w>2 \mathrm{~m} \mathrm{~s}^{-1}\right)$ emphasized as black arrows (Fig. 8a). A consistent updraft tube is evident between distances 81 and $85 \mathrm{~km}$ (from Poldirad), collocated with a "tower" of high reflectivity between altitudes of 7 and $11 \mathrm{~km}$. Second, radial Doppler-velocities from Poldirad (Fig. 8b) essentially confirm the retrieved wind directions for the selected section; the blue region part bounded by altitudes between 7 and $12 \mathrm{~km}$ and by horizontal ranges of 73 to $80 \mathrm{~km}$ corresponds well with the predominant wind direction towards Poldirad in Fig. 8a. Coloured contours in Fig. 8b surround areas where retrieved winds differ from Poldirad radial velocities by more than $4 \mathrm{~m} \mathrm{~s}^{-1}$ (retrieved minus measured differences are positive/negative within the red/blue contour line). Finally, these areas of enhanced discrepancy are located between 6 and $8 \mathrm{~km}$ altitude and coincide with regions where the Poldirad parameter "spectral width of radial velocity" exceeds $4 \mathrm{~m} \mathrm{~s}^{-1}$ (Fig. 8c), which generally serves as an indicator for enhanced turbulence within the measurement volume.

For the rapid development phase of the thunderstorm, the multiple-Doppler retrievals operated near the limit of meaningful temporal resolution (imposed by the fixed scanning routines). Nevertheless, the presented combination of various data sources revealed a consistent picture of the predominant regions of vigorous in-cloud turbulence within the storm.

\subsection{Relationship between lightning and updraft}

Corresponding to the intense dynamics documented by the radar analysis, two lightning flashes, divided into eight lightning strokes were detected between 14:40 and 14:42 inside the $1 \mathrm{~km}$ range of the selected RHI-plane (Fig. 8c). The locations of ground and cloud lightning strokes are concentrated near the $82 \mathrm{~km}$ range distance from Poldirad at the south-east flank of the thundercloud. These lightning positions complete the dynamic picture of the current state, because of matching well with the region of enhanced dynamics in Fig. 8c and with the updraft tube - indicated by the black arrows and the reflectivity tower in Fig. 8a.

Because of the low time resolution of 15 min interval from the triple-Doppler analysis compared to only $12 \mathrm{~min}$ of lightning occurrences, no statistical correlation could be composed for an updraft-lightning relationship. However the spatial distribution of updraft depth from triple-Doppler analysis at $14: 35$ (considering only updraft exceeding $5 \mathrm{~m} \mathrm{~s}^{-1}$ ) was compared to lightning locations in Fig. 9. For this, the 69 lightning strokes were grouped into 22 lightning flashes by combining strokes within $2 \mathrm{~s}$ and $30 \mathrm{~km}$. (Note, the grouping result does not depend on the choice of parameters; in fact the same results were achieved by changing the parameters by a factor of 2.)

The temporal evolution of lightning flashes in Fig. 9 is denoted by labels with two-minute time intervals starting with first flash at 14:39. Besides the latest lightning flash location at 14:45 (marked as number 6) and the single point (marked as 1), lightning positions match well within the area of extended updraft. Note, both lightning flashes, marked as number 4, are displayed at RHI scan in Fig. 8c. However besides lightning strokes belonging to flash number 6 , all strokes positions are displayed in Fig. 4 which demonstrates the relationship between deep vertical motion and lightning as well. By summarizing all updrafts exceeding $5 \mathrm{~m} \mathrm{~s}^{-1}$ and $10 \mathrm{~m} \mathrm{~s}^{-1}$, the updraft volume at 14:35 above the melting zone $\left(>5 \mathrm{~km}\right.$ ) was estimated to $210 \mathrm{~km}^{3}$ and $16 \mathrm{~km}^{3}$, respectively. Together with results from Palucki et al. (2011) which determined an updraft $\left(>5 \mathrm{~m} \mathrm{~s}^{-1}\right)$ volume of $25 \mathrm{~km}^{3}$ for a less 


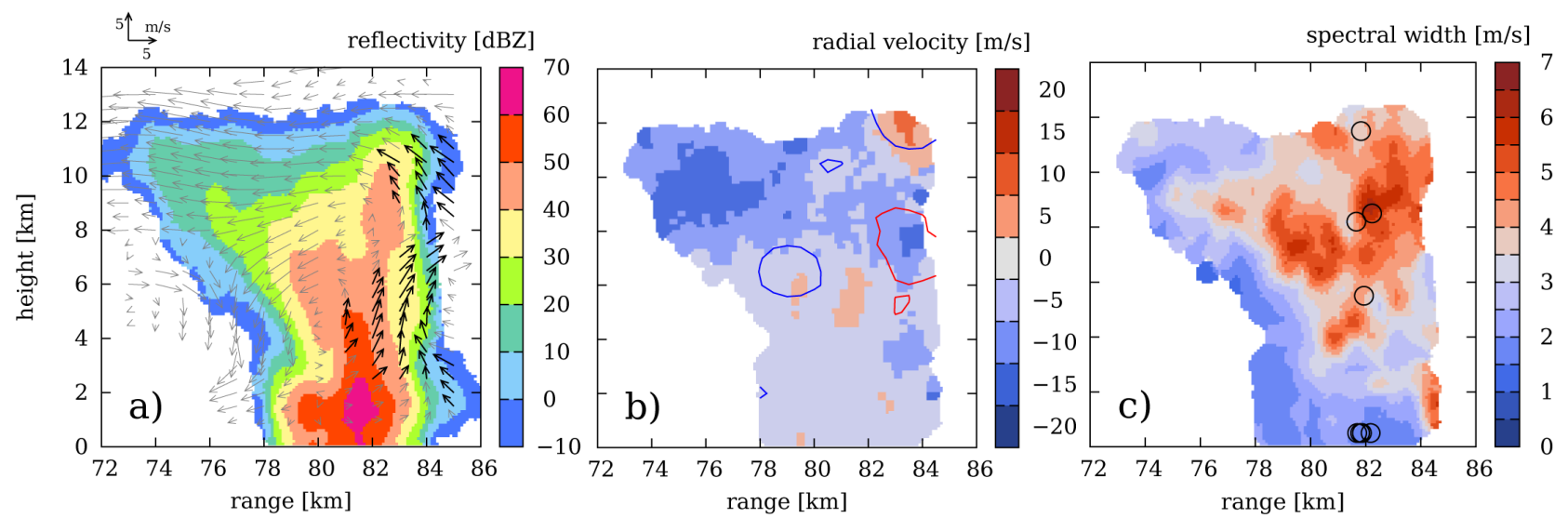

Fig. 8. Detailed wind field parameters of RHI scan from Poldirad at 14:43: (a) reflectivity with overlaid wind field (black arrows mark updrafts $>2 \mathrm{~m} \mathrm{~s}^{-1}$ ) from fourfold-Doppler analysis projected onto RHI-plane (red line in Fig. 3b), (b) measured radial velocity by Poldirad with marked areas of retrieval discrepancies (see text for details), and (c) Doppler spectral width with overlaid lightning positions (black circles within less than $1 \mathrm{~km}$ from RHI-plane).

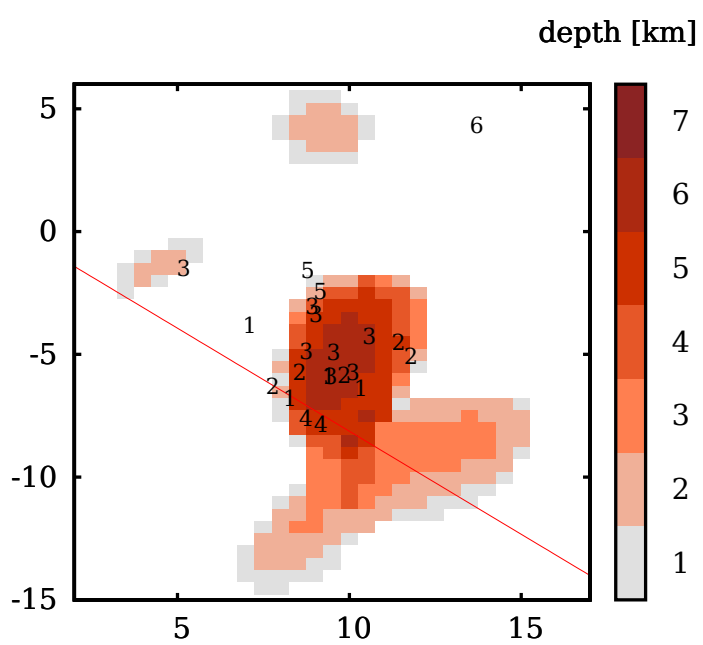

Fig. 9. Collocation of lightning positions and depth of vertical updraft columns (with threshold of $5 \mathrm{~m} \mathrm{~s}^{-1}$ ) from triple-Doppler analysis at 14:35 UTC (see rectangle in Fig. 3a). Lightning flashes are labelled by two-minute intervals, with "1" starting at 14:39 UTC; red line denotes position of RHI scan shown in Figs. 8 and 10.

active, two-flash-producing thunderstorm, this result is interpreted as a further indicator, that the number of flashes is related to the updraft volume.

\subsection{Classification of hydrometeors}

The evolution of hydrometeor distribution during the thunderstorm's lifetime is evaluated by using polarimetric radar data from vertically high resolved RHI scans from Poldirad. Up from 14:43, these RHI scans were taken every ten minutes for five different azimuth angles with an increment of two degrees. In detail, the hydrometeor content is estimated for the south-easterly flank during the early mature phase, de- noted as red line $\left(130^{\circ}\right.$ scan $)$ in Fig. 3b. A first indicator for the presence of hail in the lower part of the thundercloud is the high reflectivity $(>60 \mathrm{dBZ}$ ) at the distance of $82 \mathrm{~km}$ and a "hail spike" at $86 \mathrm{~km}$ (Fig. 8a) due to multiple scattering waves.

By analyzing ZDR in Fig. 10a, the melting layer is identified between 2 and $3 \mathrm{~km}$ altitude. While below $3 \mathrm{~km}$, positive ZDR values (between 3 and $4 \mathrm{~dB}$ ) are prevailing, the upper part is dominated by ZDR values around zero. These are indicators for large rain drops below and the presence of ice particles above the melting level. High LDR values $(>-30 \mathrm{~dB})$ in Fig. 10b mark the region of large or mixed hydrometeors, which is interpreted as large or wet ice particles above the melting layer, and a rain-ice mixture (up to wet hail stones) below. The strong hail differential reflectivity (HDR) over $32 \mathrm{~dB}$ at around $3 \mathrm{~km}$ documents the evidence of large ice particles, typically hail in this region. The local maximum at the HDR signal exceeding $10 \mathrm{~dB}$ at $1.5 \mathrm{~km}$ altitude is a further indicator for the probability that hail could reach the ground. Summarizing the interpretation of polarimetric radar parameters by using hydrometeor classification according to Höller et al. (1994) in Fig. 10d, we can state that below the melting layer, (strong) rain was found in some regions mixed with hail. Furthermore, the upper left part of the cloud consists of dry ice particles (snow), at the centre wet ice crystals known as graupel dominates. The rain "outliers" in the upper part collocated with high ZDR spreading are corresponding with an enhanced Doppler spectral width (Fig. 10c) in this area and point to tight link between microphysical development and turbulent dynamics.

To document the life cycle of convection, hydrometeor types are evaluated in a statistical manner. For all available RHI scans in every 10-min-intervals, four hydrometeor classes were determined. They were counted for each altitude and finally standardized by dividing by all used points 

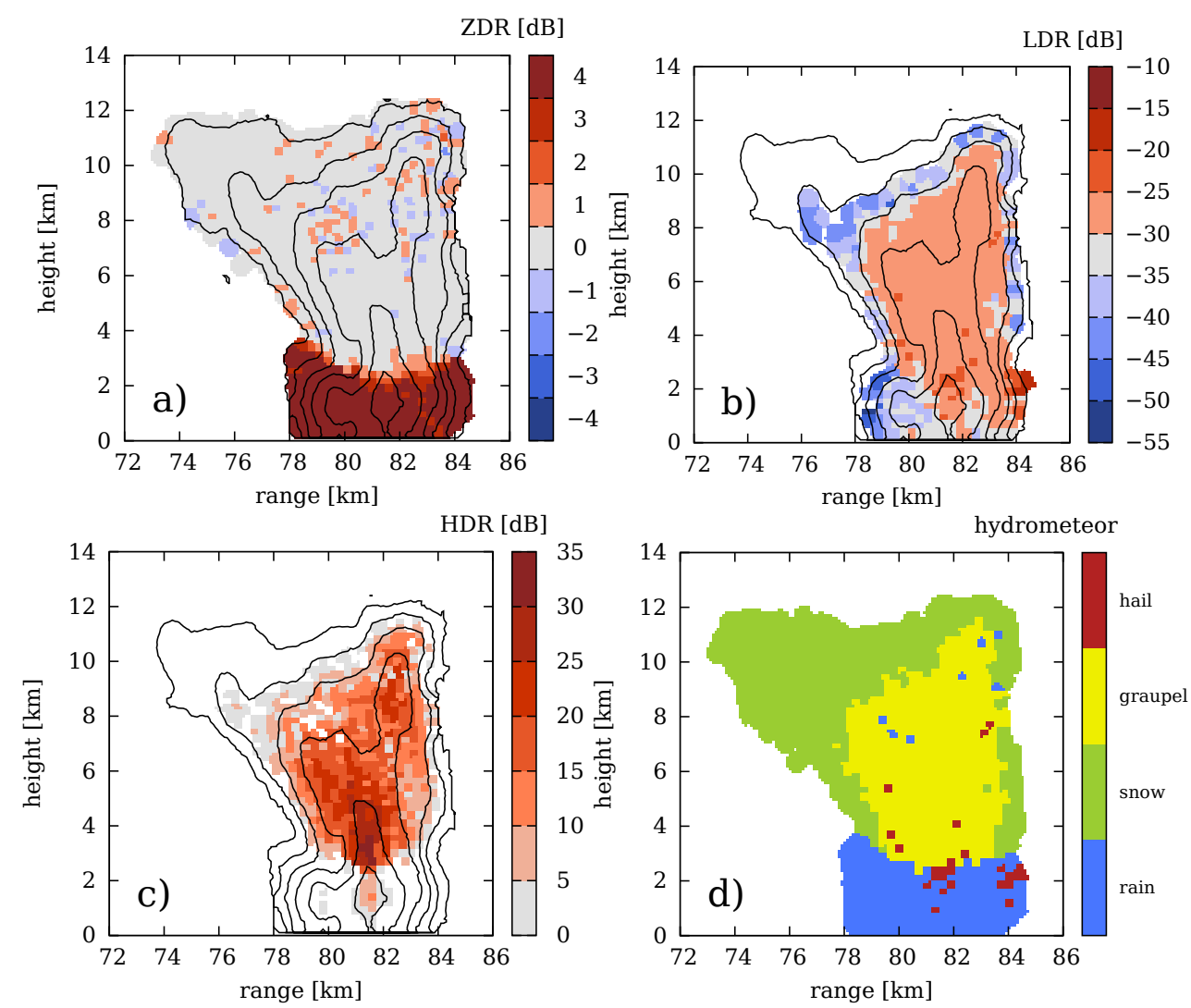

Fig. 10. Polarimetric radar parameters within RHI scan from Poldirad at 14:43: (a) differential reflectivity ZDR, (b) linear polarization ratio LDR, (c) differential reflectivity hail signal HDR, and (d) hydrometeor classification after Höller et al. (1994). Black lines in (a) to (c) denote ordinary reflectivity contours from $10 \mathrm{dBZ}$ in intervals of $10 \mathrm{dBZ}$.

in the volume. The result is a volume fraction for each type of all altitude levels (Fig. 11). Figure 11a shows the cloud during the early phase of the mature state, in which hail was classified in a fraction of $3 \%$ of total volume. At 14:43 snow exhibited the highest volume fraction at an altitude of $10 \mathrm{~km}$. Corresponding to decreasing cloud top height the maximum of snow occurrences decreased to the $5 \mathrm{~km}$-height by 15:13. The shape of the graupel-profile was similar to the snowprofile but with the maximum at lower altitudes. The fraction of rain within the whole volume increased during the dissipation of the thunderstorm, while the absolute number of classified rain bins decreased.

\subsection{Time evolution of cloud top height}

As seen in Fig. 2, radar derived cloud-top heights reached its maximum approximately at 14:40. Finally, after the last lightning flash at 14:45, the decay process was in progress. The accurate extend of cloud-tops was evaluated by using parallax corrected cloud-top pixel positions from MSG infrared channel $(10.8 \mu \mathrm{m})$ and radar based triple-Doppler results (Fig. 12). As shown in Fig. 2, lower brightness temperatures correspond well with higher radar cloud-top heights. As seen in Fig. 12b and 12c cold MSG pixels are inside the
12 or $13 \mathrm{~km}$ contour line from radar. But at 15:20, cloud-top height derived from brightness temperature differ from radar derived one, as seen in Fig. 2 as well as pixel pattern and contour lines in Fig. 12d. A possible reason for this phenomenon could be the ice shield located at the upper part of the cloud (e.g. seen at visible channel in Kalthoff et al., 2009, Fig. 2d). These smaller ice particles could only be detected by infrared data from MSG satellite but not by the radar (Fig. 13, bottom).

The satellite images of visible high resolution channel, infrared red channel and low-level radar reflectivity of this COPS case were displayed and compared e.g. by Kalthoff et al. (2009) and Aoshima et al. (2008). A detailed view of the location accuracy shows that the first radar reflectivity area at 14:30 matched well with the location of low brightness temperature from infrared channel and reflectance from high resolution visible channel of MSG satellite. While the cell seen by the satellite moves northeastwards, the radar cell moves slowly in a more easterly direction. The reason is given by different wind directions in different altitude levels. While infrared and visible channel observed the top of the cloud, the 5 min precipitation radar scan from Feldberg at $0.8^{\circ}$ elevation monitors the lower cloud region approximately 1 to $2 \mathrm{~km}$ 

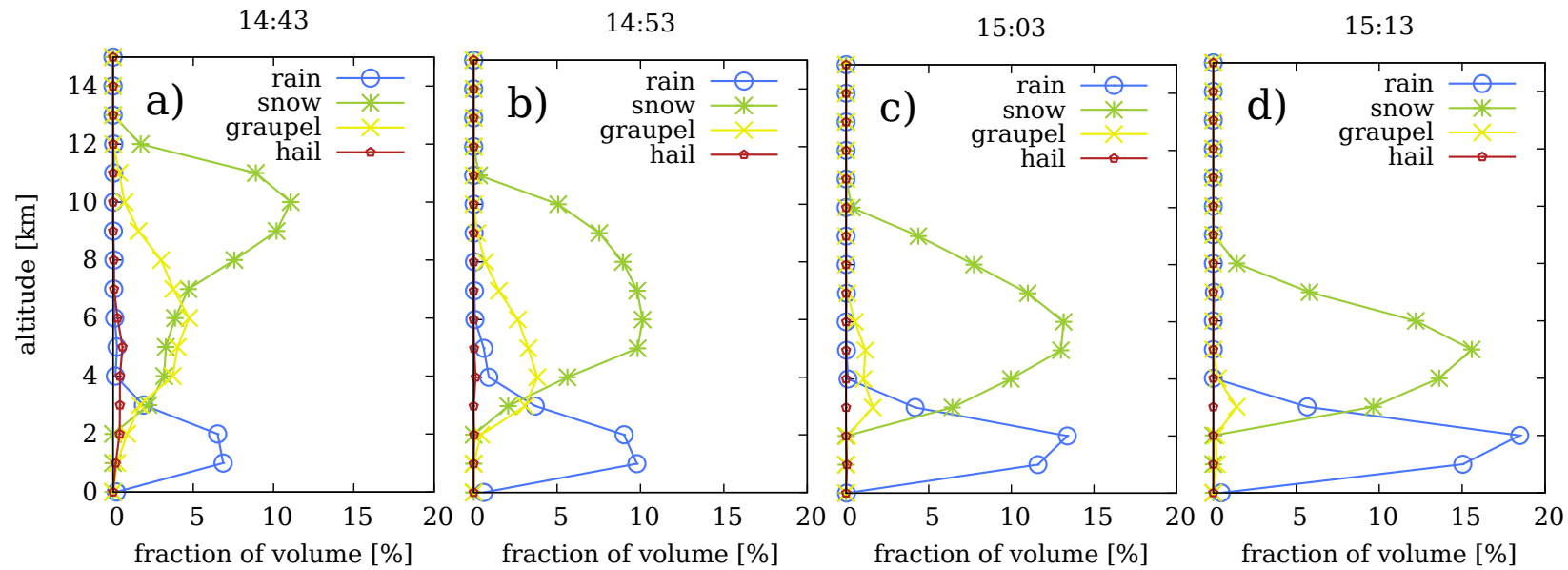

Fig. 11. Time evolution of hydrometeor profiles obtained from adjacent RHIs of Poldirad.

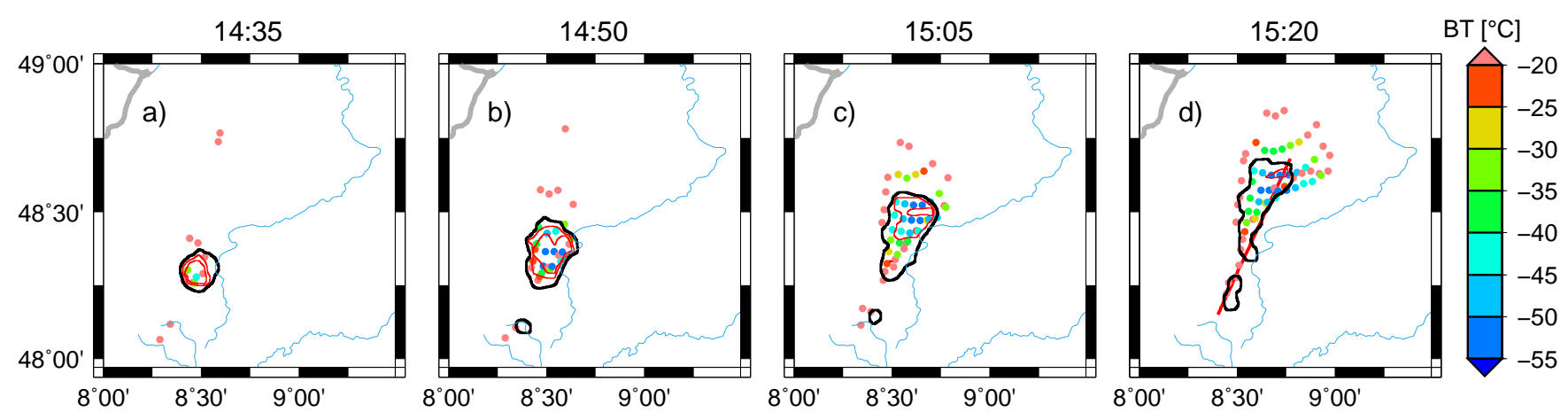

Fig. 12. Location and extent of cloud-top structure using parallax corrected cloud-top positions from Meteosat (dots with color coded IR brightness temperature) and triple-radar derived cloud-top height as contours (black: $8 \mathrm{~km}$, red: $12 \mathrm{~km}$ and $13 \mathrm{~km}$ ). Red line in (d) marks vertical cross section displayed in Fig. 13.

altitude (MSL) at this area (not shown). As seen in Fig. 13 (top), the cloud at 15:20 was stretched over a range of more than $60 \mathrm{~km}$. While strong winds $\left(>20 \mathrm{~m} \mathrm{~s}^{-1}\right)$ from south occurred at the northern upper part $(30-50 \mathrm{~km}$ range and $8-$ $12 \mathrm{~km}$ altitude) and slow to medium winds (5-10 $\left.\mathrm{m} \mathrm{s}^{-1}\right)$ blew from the south-west at the central bottom part $(10-15 \mathrm{~km}$ range, $2 \mathrm{~km}$ altitude).

\subsection{Cross-validation with simulated flow structure}

Data from atmospheric field experiments are regularly used to increase the understanding of physical processes relevant during the sampled episodes and to aid the validation process of appropriate simulation models, which ultimately aim at reliable operational forecasts. They assist to establish a close link between the natural laboratory of the atmosphere and the numerical laboratory of the modelling system (Volkert and Gutermann, 2007). In this section we exemplify how a tight combination of satellite and radar data retrievals with results from non-hydrostatic nested simulations contributes to the cross-validation (Hollingsworth, 1994) of observation and simulation, as both domains contain inevitable uncertainties.

The mesoscale non-hydrostatic modelling system Meso$\mathrm{NH}$ is applied for 15 July 2007 in episode-mode, the initial conditions were obtained from the ECMWF analysis of 15 July, 00:00 UTC, and the boundary conditions for the outermost domain were interpolated from the 6-hourly ECMWF forecasts. The model setting is identical to the one described by Richard et al. (2011). Additionally, a 4th embedded nest of $180 \times 190$ grid points over the central portion of the Black Forest was included with $500 \mathrm{~m}$ horizontal grid size and 50 levels in the vertical direction (10 of them located in the first $\mathrm{km}$ above ground). Model generated radar reflectivity fields, obtained through the application of a forward operator (details in the appendix of Richard et al., 2003) allow to depict the calculated mid-level flow analogously to the multipleDoppler analysis at 15 min intervals (Fig. 14). At 14:35 two small reflectivity cores are evident which progress with the rather uniform flow towards NNE. Pronounced updrafts and downdrafts are located at the southern side of the united cells where the horizontal flows becomes severely disturbed. 

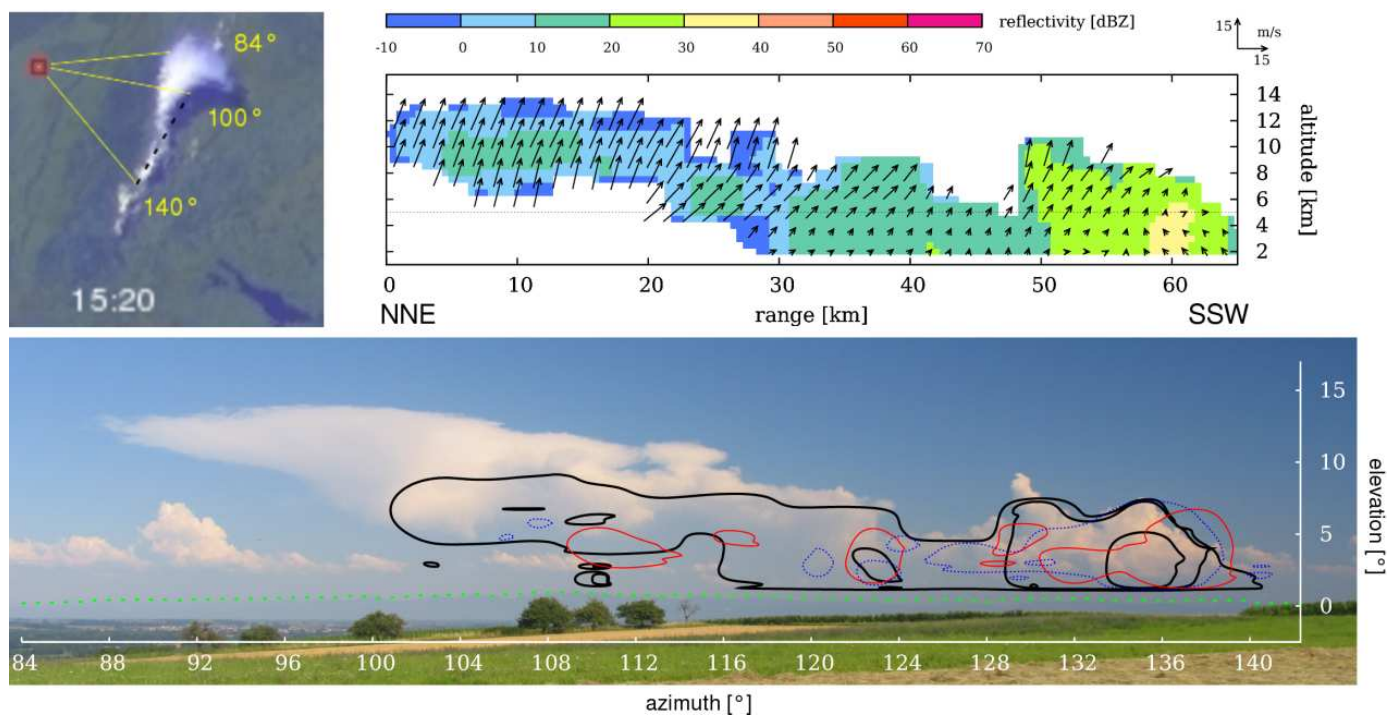

Fig. 13. Dissipation of thundercloud at 15:20 UTC. Top-right: vertical cross section from triple-Doppler analysis with averaged reflectivity and horizontal wind vectors (only every fourth vector is plotted, the dotted line marks the level of Fig. 3). Top-left: Meteosat visible channel with Poldirad location (red square), position of cross section (black line), and viewing directions (yellow lines) of cross section and photo. Bottom: levelled photograph taken from Poldirad site at 15:24 (recovered terrain silhouette as dashed green line), overlayed with maximum triple-Doppler radar reflectivity (black contours at 10, 20 and $30 \mathrm{dBZ}$ ), updrafts higher than $2 \mathrm{~m} \mathrm{~s}^{-1}$ (red), and downdrafts lower than $-2 \mathrm{~m} \mathrm{~s}^{-1}$ (blue) along lines of sight.
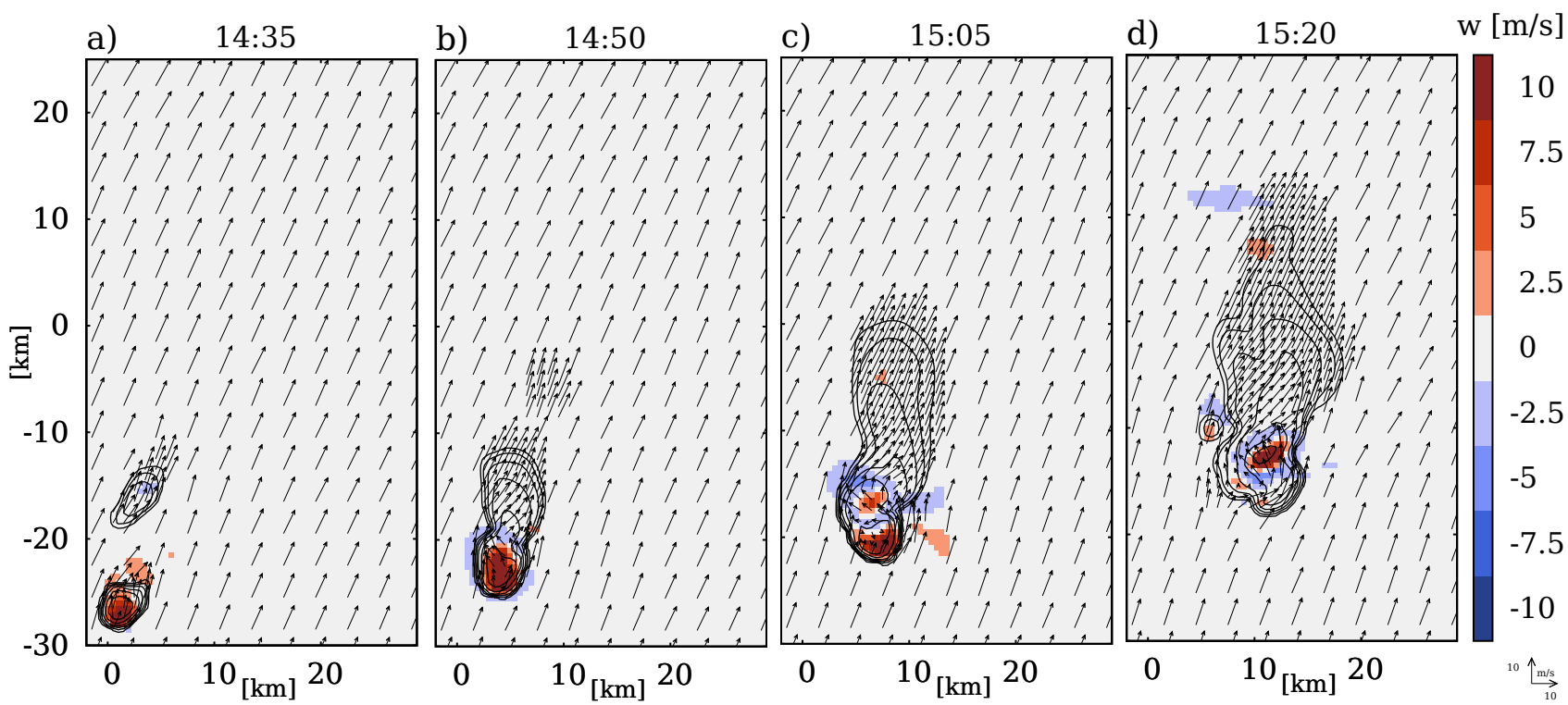

Fig. 14. Simulated cloud characteristics: reflectivity as black isolines ( $10 \mathrm{dBZ}$ intervals, starting from $10 \mathrm{dBZ}$ ), horizontal wind (arrows) and vertical motion (color coded) at $5 \mathrm{~km}$ from Meso-NH episode simulation nested down to $0.5 \mathrm{~km}$ horizontal resolution.

Compared with the integrated observational result (Fig. 3) the simulated cells are at about the same location, but smaller in horizontal extent and embedded in a more southerly flow. We note that the multiple Doppler flow analysis mainly relies on the relative movements of hydrometeors, while the algorithm extrapolates the flow outside of the reflectivity zones to the prescribed background profile. In the simula- tion, however, the slowly evolving background flow is provided from the larger scale initial fields and "handed downwards" through the four computational nests while the spatial resolution gets finer and finer. Comparative information of retrieved and simulated flow structures within the cloud and around are given for the altitudes levels $3,5,7$, and $9 \mathrm{~km}$ 


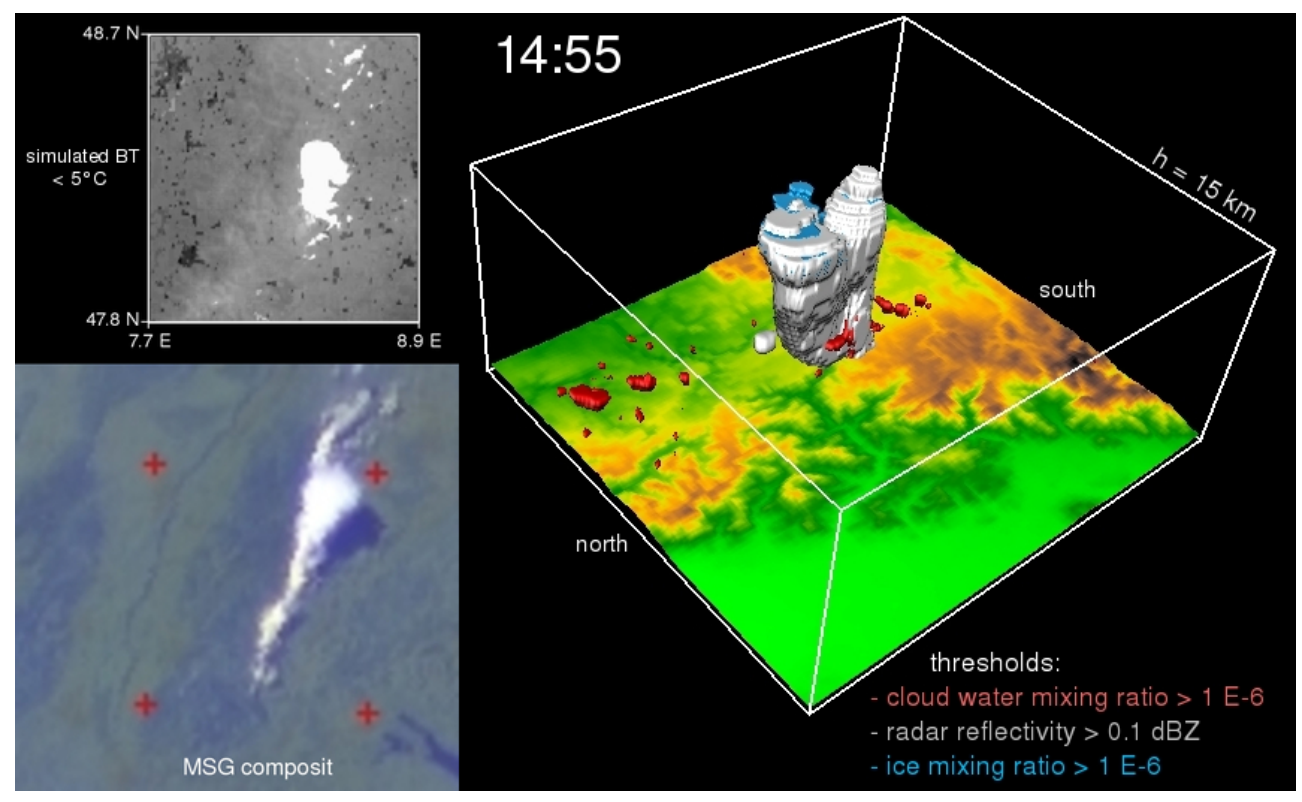

Fig. 15. Observation versus simulation at 14:55. Top left: model generated brightness temperature; values below $5^{\circ} \mathrm{C}$ in white. Bottom left: three-channel MSG composite with Vosges, Rhine valley, and elongated cloud system above the eastern part of the Black Forest; red crosses denote corners of the nested simulation domain. Right: perspective view from NW on the 15-km-high computational box above the model topography; thresholds for iso-surfaces are indicated for cloud water (red), radar reflectivity (white), and ice water (blue).

in the Supplement as animated loop (movie3.mpg) and as 18 separate frames (in directory 4-levels-rad-mod).

A loop through 48 triple images at 5-min-intervals between 12:05 and 16:00 (movie4.mpg from Supplement) exemplifies both the remarkable agreement between observation and simulation as well as apparent discrepancies. In plan view, a blow-up of the cloud extent as seen by MSG is juxtaposed to the model generated brightness temperature (BT) within the complete fourth nest of $90 \mathrm{~km}$ (west-toeast) $\times 95 \mathrm{~km}$ (south-to-north) extents. More simulation information is contained in a perspective view from the NW onto the simulation domain above the surface topography of the Black Forest and its valleys: red cells enclose values of cloud water mixing ratio $>1 \mathrm{mg} \mathrm{kg}^{-1}$ as a proxy for developing cumuli, the white towering volumes contain reflectivities above $0.1 \mathrm{dBZ}$, and blue surfaces stand for an ice water mixing ratio of $>1 \mathrm{mg} \mathrm{kg}^{-1}$ as a proxy for anvil cirrus. Around 13:00 cool spots of $\mathrm{BT}<5^{\circ} \mathrm{C}$ and red cloud spots are aligned over the eastern heights roughly along $8.4^{\circ}$ east in accord with the observation. First reflectivity cores appear over the southern Black Forest by 13:20. The latter move northwards along the apparent convergence line and shoot up above mid-tropospheric levels by 14:00. The most active part remains in the rear of the convective system, which reaches up to $13 \mathrm{~km}$ by $15: 00$ and has nearly collapsed $1 \mathrm{~h}$ later. The vertical steps in the reflectivity volume depict the vertical grid-spacing of about $500 \mathrm{~m}$ at high elevations. The snapshot of 14:55 (Fig. 15) depicts the double-reflectivity-tower with a common base above the upper Kinzig valley, while the observed cirrus anvil was already reaching the north-eastern corner of the area of special interest.

The detailed observational results presented in this section began to serve as starting point for a series of sensitivity experiments using Meso-NH. So far we can conclude that the initiation of deep convection on 15 July 2007 was only possible along the mesoscale convergence line along the Black-Forest crest. The eventual development, however, was restricted to the much smaller region above the elevated plain to the east of the Kinzig valley and between the still higher crest regions of the northern and southern Black Forest. Details of the simulated storm depend to a high degree on the details of microphysical scheme. In the present run for instance, the role of hail appears to be over-represented. Model generated average profiles of hydrometeors (cf. Fig. 11) will be used to adjust microphysical parameters.

\section{Discussion and conclusion}

In this study diverse data sources were combined in a synoptic, i.e. together viewing, manner in analogy to classical weather chart analysis. Images and data from geostationary satellite observations, calibrated ground based photography, multiple radar measurements and observed lightning positions put together provide important extensions to the previous studies regarding the short-lived, isolated thunderstorm of 15 July 2007 during COPS, in particular for the phases of rapid development and maturation. Generally, deep convection was not favoured on that day as CAPE and CIN attained 


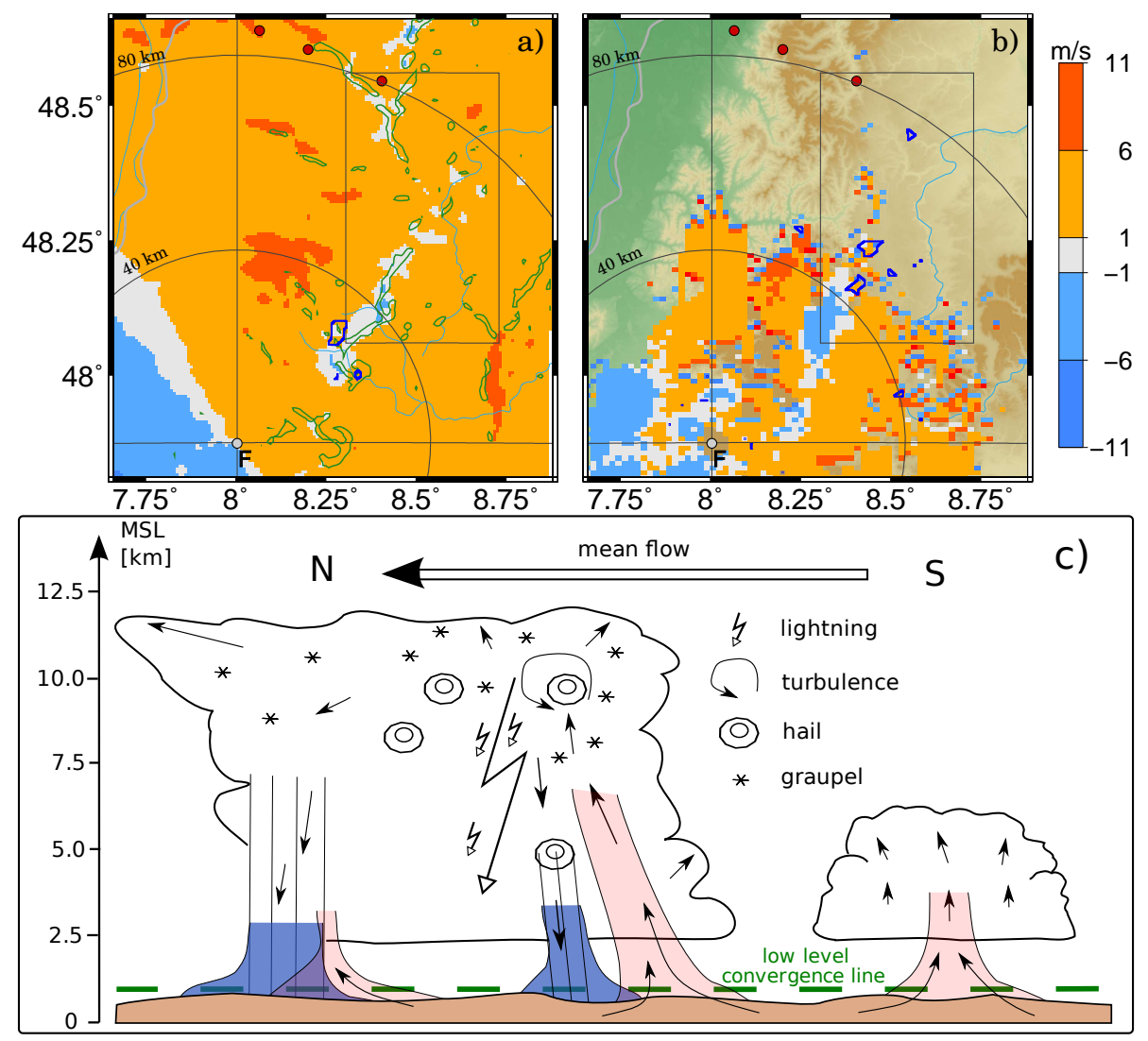

Fig. 16. Cross-validating pieces of evidence from (a) simulation and (b) radar observation at 14:00 UTC: Low level convergence $\left(>0.002 \mathrm{~s}^{-1}\right)$ at $1 \mathrm{~km}(\mathrm{MSL})$ within green contours (a) as prerequisite for convection development coinciding with the shear-line in the radial velocity at $2 \mathrm{~km}$ (MSL) relative to the Feldberg radar site (F; positive values: towards; negative ones away from the radar). Maximal radar reflectivity between 3 and $7 \mathrm{~km}$ altitude $(0 \mathrm{dBZ}$ contour in blue) serves as proxy for starting cloud development. Schematic cross-section of the thunderstorm's dimensions above the low level convergence with updrafts, downdrafts, and other documented ingredients (c).

only moderate and high values, respectively. Upward forcing near the ground, however, triggered small cumuli after noon along a contiguous convergence line along the eastern part of the Black Forest. Deeper development only happened in its middle, apparently instigated by channelled mesoscale flow at low levels along the western edge of the southern Black Forest, as the high resolution simulation indicates (figure not shown). Animated loops of images separated by $5 \mathrm{~min}$ from both, multi-channel satellite imagery on a weather map projection as well as simulation generated brightness temperatures and reflectivity cores put the deep convection event at the threshold between a single storm with several updrafts cores and a multi-cell systems composed of a few smaller cells. A juxtaposition of retrieved and simulated data in the same format helps to narrow the gap between the natural and the numerical laboratory (Fig. 16). For 14:00, the mesoscale convergence line to the east of the Black Forest crestline left a clear signal in form of the radial velocity shear line detectable within $40 \mathrm{~km}$ around the Feldberg radar and reconstructed from the simulated flow at $2 \mathrm{~km}$. The full pattern of boundary layer convergence (at $1 \mathrm{~km}$ MSL) can only be determined from the simulation. Apparently it took a few "puffs" of cumulus development to overcome CIN and to realize the CAPE aloft. Once deep convection started to set in, the bulk of the boundary layer moisture was suck into one large cell. A schematic lateral view of the main cloud and its dimensions concludes Fig. 16 together with the typical locations of important detected features as updraft and downdraft cores, lightning, turbulence, graupel and hail.

Only the largest cell above the elevated, almost level ground, which separates the southern Black Forest from its northern part, contained a sufficiently strong and lasting updraft volume, so that numerous lightning strokes were generated making up about two dozens flashes. Its vertical development was most rapid between 14:20 and 14:35 with upward motion of $10 \mathrm{~m} \mathrm{~s}^{-1}$ at $9 \mathrm{~km}$. During the next $10 \mathrm{~min}$ in-cloud activity was found to be strongest comprising pronounced updrafts collocated with registered lightning positions. An empirical linear relationship, from New Mexico cases, between the volume of updrafts exceeding a specified threshold was confirmed for our European case. At the same 
time and location polarimetric measurements indicate the existence of hail.

The collage-style combination of three consecutive satellite scenes from geostationary orbit ( $\sim 36000 \mathrm{~km}$ away) and lateral, ground-based cloud photography ( $\sim 80 \mathrm{~km}$ away) with multi-radar retrievals and lightning locations provides (i) valuable consistency checks between the observing systems and retrieval algorithms and (ii) an instructive visualization of the system's transient nature and of the observations' spatio-temporal limits. Vertical profiles of kinematic quantities over the entire main cell are available for four instants separated by $15 \mathrm{~min}$. They reveal the rather uniform wind direction above $3 \mathrm{~km}$ and updrafts dominating downward-motion only during the first quarter of an hour. Vertical RHI-slices of various radar-quantities from Poldirad were used to put the mentioned statistics in perspective and to obtain a range-height distribution of the hydrometeor classes rain, snow, graupel and hail. A five-fold vertical slicing of the moving core cell during for four consecutive 10-minintervals was used to derive vertical profiles of volume fraction of the hydrometeors. Hail was detected only at the first instance (14:43), while the maxima of the other categories descended with time. Finally, the strom's dissipation phase is compactly documented by a juxtaposition of wide-angle lateral photography, satellite view and an along cloud section of multi-radar retrieved reflectivity and horizontal flow. A distinct separation becomes evident of the north-eastward progressing anvil and diminishing convective cells behind.

A central result of the study is the fine scale determination ( $500 \mathrm{~m}$ resolution in all three directions) of airflow within the thundercloud's radar reflectivity as retrieved at 15-minintervals from a triple-Doppler analysis (Fig. 3). Within the growing and north-eastward progressing reflectivity cores, horizontal winds are significantly disturbed relative to the rather uniform flow of their environment. The strongest updrafts are located at the right rear-side of the cores. The display of the simulated winds field, determined for the same one-hour-period on a similarly dense fourth grid (Fig. 14), reveals at the same time (i) a remarkable agreement in location, timing and overall strength of the cells, which were solely generated by the evolving larger scale environment initialized by the numerical weather prediction analysis some $14 \mathrm{~h}$ earlier, and (ii) discrepancies in cell size, size and strength of the horizontal flow disturbance, plus extent and spatial distribution of distinct updraft and downdrafts. The observational flow, hydrometeor and lightning datasets appear to be of particular value when results of systematic sensitivity simulations can be displayed in the same fashion. Modelling studies including electrification were started using this IOP-8b case of COPS as a reference.

The overall value of this study is regarded to be fourfold:

- previous investigations about the initiation and overall nature of the only isolated and strong thunderstorm during COPS were extended by detailed glimpses into the systems mature and decaying phase, not the least through time lapse movie loops from MSG rapid scan scenes;

- the synoptic perspective based on a variety of passive and active remote sensing systems and ground based photography (approximating the vision of a human observer) clearly showed that deep convection was eventually sparked in a very confined area at the saddle point between the Black Forest's highest parts;

- comparisons with a high resolution numerical weather prediction simulation in research mode provided valuable cross-validation between both independent approaches, but also exemplified the narrowed, yet still evident gap between details in observation and simulation; the motivation to further sensitivity studies, e.g. regarding variants in the microphysical scheme or lightning parametrizations became evident; and finally,

- this case study can also serve as an instructive example for the growing importance of computational tools in the knowledge generating process of science (Gramelsberger, 2011).

Sophisticated algorithms have to be applied and a lot of purpose-built computing has to be undertaken in both areas which are independent from another: the data retrievals using distributed sensors, wavelengths, and polarizations as well as the initial-value dynamical simulations with grid-nesting and a full fleet of physical parametrizations. Though modest in size and duration, the isolated thunderstorm over the central Black Forest will continue to play its role as benchmark case for the realistic simulation of deep convection.

\section{Supplementary material related to this article is available online at: http://www.atmos-chem-phys.net/12/ 6679/2012/acp-12-6679-2012-supplement.zip.}

Acknowledgements. This work was supported by the Deutsche Forschungsgemeinschaft (DFG) in the Priority Program SSP 1167 "Quantitative Precipitation Forecast". Deutscher Wetterdienst (DWD), the Karlsruhe Institute for Technology (KIT) and Nowcast $\mathrm{GmbH}$ provided radar and lightning data via the COPS database. Kaspar Graf and Hermann Mannstein (both DLR) processed the MSG images, Winfried Beer (DLR) helped to level the photographs, Bob Houze (University of Washington) pointed to references of previous case studies, Peter Meischner and Caroline Forster (both DLR) commented on earlier versions of the manuscript. Daniel Kirshbaum (McGill) and Christian Barthlott (KIT) helped to sharpen the line of argumentation by providing indepth reviews. All this assistance is acknowledged with gratitude.

Edited by: H. Wernli 


\section{References}

Aminou, D.: MSG's SEVIRI instrument, ESA Bulletin, 111, 15-17, http://www.esa.int/esapub/bulletin/bullet111/chapter4_bul111. pdf, 2002.

Aoshima, F., Behrendt, A., Bauer, H., and Wulfmeyer, V.: Statistics of convection initiation by use of Meteosat rapid scan data during the Convective and Orographically-induced Precipitation Study (COPS), Meteorol. Z., 17, 921-930, 2008.

Aydin, K., Seliga, T., and Balaji, V.: Remote sensing of hail with a dual linear polarization radar, J. Clim. Appl. Meteorol., 25, 1475-1484, 1986.

Barthlott, C., Schipper, J., Kalthoff, N., Adler, B., Kottmeier, C., Blyth, A., and Mobbs, S.: Model representation of boundarylayer convergence triggering deep convection over complex terrain: A case study from COPS, Atmos. Res., 95, 172-185, doi:10.1016/j.atmosres.2009.09.010, 2010.

Barthlott, C., Burton, R., Kirshbaum, D., Hanley, K., Richard, E., Chaboureau, J.-P., Trentmann, J., Kern, B., Bauer, H.-S., Schwitalla, T., Keil, C., Seity, Y., Gadian, A., Blyth, A., Mobbs, S., Flamant, C., and Handwerker, J.: Initiation of deep convection at marginal instability in an ensemble of mesoscale models: a case-study from COPS, Q. J. Roy. Meteorol. Soc., 137, 118136, doi:10.1002/qj.707, 2011.

Behrendt, A., Pal, S., Aoshima, F., Bender, M., Blyth, A., Corsmeier, U., Cuesta, J., Dick, G., Dorninger, M., Flamant, C., Di Girolamo, P., Gorgas, T., Huang, Y., Kalthoff, N., Khodayar, S., Mannstein, H., Träumner, K., Wieser, A., and Wulfmeyer, V.: Observation of convection initiation processes with a suite of state-of-the-art research instruments during COPS IOP 8b, Q. J. Roy. Meteorol. Soc., 137, 81-100, doi:10.1002/qj.758, 2011.

Betz, H., Schmidt, K., Oettinger, P., and Wirz, M.: Lightning detection with 3-D discrimination of intracloud and cloud-to-ground discharges, Geophys. Res. Lett., 31, L11108, doi:10.1029/2004GL019821, 2004.

Bousquet, O., Tabary, P., and du Châtelet, J.: Operational MultipleDoppler Wind Retrieval Inferred from Long-Range Radial Velocity Measurements, J. Appl. Meteorol. Climatol., 47, 29292945, doi:10.1175/2008JAMC1878.1, 2008.

Browning, K. and Ludlam, F.: Airflow in convective storms, Q. J. Roy. Meteorol. Soc., 88, 117-135, 1962.

Chong, M. and Testud, J.: Three-dimensional wind field analysis from dual-doppler radar data. Part III: the boundary condition: An optimum determination based on a variational concept, J. Clim. Appl. Meteorol., 22, 1227-1241, 1983.

Chong, M., Georgis, J., Bousquet, O., Brodzik, S., Burghart, C., Cosma, S., Germann, U., Gouget, V., Houze Jr., R., James, C., Prieur, S., Rotunno, R., Roux, F., Vivekanandan, J., and Zeng, Z.-X.: Real-Time Wind Synthesis from Doppler Radar Observations during the Mesoscale Alpine Programme, B. Am. Meteorol. Soc., 81, 2953-2962, 2000.

Cotton, W. and Anthes, R.: Storm and cloud dynamics, Academic Press, 1989.

Deierling, W. and Petersen, W.: Total lightning activity as an indicator of updraft characteristics, J. Geophys. Res., 113, D16210, doi:10.1029/2007JD009598, 2008.

Deierling, W., Petersen, W., Latham, J., Ellis, S., and Christian, H.: The relationsship between lightning activity and ice fluxes in thunderstorms, J. Geophys. Res., 113, D15210, doi:10.1029/2007JD009700, 2008.
Dolan, B. and Rutledge, S.: An integrated display and analysis methodology for multivariable radar data, J. Appl. Meteorol. Climatol., 46, 1196-1213, doi:10.1175/JAM2524.1, 2007.

Fehr, T., Dotzek, N., and Höller, H.: Comparion of lightning activity and radar-retrieved microphysical properties in EULINOX storms, Atmos. Res., 76, 167-189, doi:10.1016/j.atmosres.2004.11.027, 2005.

Frame, J., Markowski, P., Richardson, Y., Straka, J., and Wurman, J.: Polarimetric and dual-Doppler radar observations of the Lipscomb County, Texas, supercell thunderstorm on 23 May 2002, Mon. Weather Rev., 137, 544-561, 2009.

Gramelsberger, G.: From Science to Computational Sciences. Studies in the History of Computing and its Influence on Today's Sciences, chap. From Computation with Experiments to Experiments with Computation, 131-142, diaphanes Zurich/Berlin, 2011.

Hanley, K. E., Kirshbaum, D. J., Belcher, S. E., Roberts, N. M., and Leoncini, G.: Ensemble predictability of an isolated mountain thunderstorm in a high-resolution model, Q. J. Roy. Meteorol. Soc., 137, 2124-2137, doi:10.1002/qj.877, 2011.

Hollingsworth, A.: Validation and diagnosis of atmospheric models, Dynam. Atmos. Oceans, 20, 227-246, 1994.

Höller, H.: Mesoscale organization and hailfall characteristics of deep convection in southern Germany, Beitr. Phys. Atmosph., 67, 219-234, 1994.

Höller, H., Bringi, V., Hubbert, J., Hagen, M., and Meischner, P.: Life cycle and precipitation formation in a hybrid-type hailstorm revealed by polarimetric and Doppler radar measurements, J. Atmos. Sci., 51, 2500-2500, 1994.

Jerome, J.: Three Men on the Bummel, www.gutenberg.org/ebooks/ 2183, 1900.

Kalthoff, N., Adler, B., Barthlott, C., Corsmeier, U., Mobbs, S., Crewell, S., Träumner, K., Kottmeier, C., Wieser, A., Smith, V., and Di Girolamo, P.: The impact of convergence zones on the initiation of deep convection: A case study from COPS, Atmos. Res., 93, 680-694, doi:10.1016/j.atmosres.2009.02.010, 2009.

Kirshbaum, D.: Cloud-resolving simulations of deep convection over a heated mountain, J. Atmos. Sci., 68, 361-378, doi:10.1175/2010JAS3642.1, 2011.

Kottmeier, C., Kalthoff, N., Barthlott, C., Corsmeier, U., Van Baelen, J., Behrendt, A., Behrendt, R., Blyth, A., Coulter, R., Crewell, S., Di Girolamo, P., Dorninger, M., Flamant, C., Foken, T., Hagen, M., Hauck, C., Höller, H., Konow, H., Kunz, M., Mahlke, H., Mobbs, S., Richard, E., Steinacker, R., Weckwerth, T., Wieser, A., and Wulfmeyer, V.: Mechanisms initiating deep convection over complex terrain during COPS, Meteorol. Z., 17, 931-948, doi:10.1127/0941-2948/2008/0348, 2008.

Krebs, W.: Analyse des Einflusses des Flugverkehrs auf die natürliche Zirrusbewölkung in Europa, Nordamerika und dem Nordatlantik, Ph.D. thesis, LMU München, 2006.

Kuhlman, K., Ziegler, C., Mansell, E., MacGorman, D., and Straka, J.: Numerically simulated electrification and lightning of the 29 June 2000 STEPS supercell storm, Mon. Weather Rev., 134, 2734-2757, 2006.

Lang, T. and Rutledge, S.: Relationships between convective storm kinematics, precipitation, and lightning, Mon. Weather Rev., 130, 2492-2506, 2002.

Lim, E. and Sun, J.: A velocity dealiasing technique using rapidly updated analysis from a four-dimensional variational doppler 
radar data assimilation system, J. Atmos. Ocean. Tech., 27, 1140-1152, doi:10.1175/2010JTECHA1300.1, 2010.

Markowski, P. and Richardson, Y.: Mesoscale meteorology in midlatitudes, Wiley-Blackwell, 2010.

Matejka, T. and Barthels, D.: The accuracy of vertical air velocities from Doppler radar data, Mon. Weather Rev., 126, 92-117, 1998.

Mecikalski, J. and Bedka, K.: Forecasting Convective Initiation by Monitoring the Evolution of Moving Cumulus in Daytime GOES Imagery, Mon. Weather Rev., 134, 49-78, doi:10.1175/MWR3062.1, 2006.

Mecikalski, J., MacKenzie Jr., W., König, M., and Muller, S.: Cloud-Top Properties of Growing Cumulus prior to Convective Initiation as Measured by Meteosat Second Generation. Part I: Infrared Fields, J. Appl. Meteorol. Climatol., 49, 521-534, doi:10.1175/2009JAMC2344.1, 2010.

Meischner, P. (Ed.): Weather radar: Principles and advanced applications, Springer-Verlag, 2003.

Miller, L. and Fredrick, S.: CEDRIC. Custom Editing and display of reduced information in Cartesian space, National Center for Atmospheric Research, http://www.eol.ucar.edu/instrumentation/airborne-instruments/ eldora/eldora-help-center/manual/cedric-reference-manual, 1998.

Mohr, C., Miller, J., Vaughan, R., and Frank, H.: The merger of mesoscale datasets into a common Cartesian format for efficient and systematic analyses, J. Atmos. Ocean. Tech., 3, 143-161, 1986.

Oye, D. and Case, M.: REORDER. A Program for Gridding Radar Data, Installation and use manual for the unix version, National Center for Atmospheric Research, http://www.eol.ucar.edu/instrumentation/airborne-instruments/ eldora/eldora-help-center/manual/reorder-reference-manual, 1995.

Palucki, J., Biggerstaff, M., MacGorman, D., and Schuur, T.: Comparison between low-flash and non-lightning-producing convective areas within a mature mesoscale convective system, Weather Forecast., 26, 468-486, doi:10.1175/WAF-D-10-05012.1, 2011.

Richard, E., Cosma, S., Tabary, P., Pinty, J.-P., and Hagen, M.: High-resolution numerical simulation of the convective system observed in the Lago Maggiore area on 17 September 1999 (MAP IOP 2a), Q. J. Roy. Meteorol. Soc., 129, 543-563, doi:10.1256/qj.02.50, 2003.

Richard, E., Chaboureau, J.-P., Flamant, C., Champollion, C., Hagen, M., Schmidt, K., Kiemle, C., Corsmeier, U., Barthlott, C., and Di Girolamo, P.: Forecasting summer convection over the Black Forest: a case study from the Convective and Orographically-induced Precipitation Study (COPS) experiment, Q. J. Roy. Meteorol. Soc., 137, 101-117, doi:10.1002/qj.710, 2011.
Roberts, R. and Rutledge, S.: Nowcasting storm initiation and growth using GOES-8 and WSR-88D data, Weather Forecast., 18, 562-584, 2003.

Schmetz, J., Pili, P., Tjemkes, S., Just, D., Kerkmann, J., Rota, S., and Ratier, A.: An introduction to Meteosat second generation (MSG), B. Am. Meteorol. Soc., 83, 977-992, 2002.

Schmidt, K., Betz, H., Oettinger, W., Wirz, M., Pinto Jr., O., Naccarato, K., Höller, H., Fehr, T., and Held, G.: A comparative analysis of lightning data during the EU-Brazil TROCCINOX/TroCCiBras campaign, in: VIII International Symposium on Lightning Protection (SIPDA), 21-25, 2005.

Shapiro, A., Potvin, C., and Gao, J.: Use of a vertical vorticity equation in variational dual-Doppler wind analysis, J. Atmos. Ocean. Tech., 26, 2089-2106, doi:10.1175/2009JTECHA1256.1, 2009.

Siewert, C., Koenig, M., and Mecikalski, J.: Application of Meteosat second generation data towards improving the nowcasting of convective initiation, Meteorol. Appl., 17, 442-451, doi:10.1002/met.176, 2010.

Tuttle, J., Bringi, V., Orville, H., and Kopp, F.: Multiparameter radar study of a microburst: Comparison with model results, J. Atmos. Sci., 46, 601-620, 1989.

Volkert, H. and Gutermann, T.: Inter-domain cooperation for mesoscale atmospheric laboratories: The mesoscale Alpine programme as a rich study case, Q. J. Roy. Meteorol. Soc., 133, 949-967, doi:10.1002/qj.95, 2007.

Wakimoto, R. and Bringi, V.: Dual-polarization observations of microbursts associated with intense convection - The 20 July storm during the MIST Project, Mon. Weather Rev., 116, 1521-1539, 1988.

Wilson, C.: Investigations on lightning discharges and on the electric field of thunderstorms, Philos. T. Roy. Soc. London A, 221, 73-115, 1921.

Wulfmeyer, V., Behrendt, A., Kottmeier, C., Corsmeier, U., Barthlott, C., Craig, G., Hagen, M., Althausen, D., Aoshima, F., Arpagaus, M., Bauer, H.-S., Bennett, L., Blyth, A., Brandau, C., Champollion, C., Crewell, S., Dick, G., Di Girolamo, P., Dorninger, M., Dufournet, Y., Eigenmann, R., Engelmann, R., Flamant, C., Foken, T., Gorgas, T., Grzeschik, M., Handwerker, J., Hauck, C., Höller, H., Junkermann, W., Kalthoff, N., Kiemle, C., Klink, S., König, M., Krauss, L., Long, C., Madonna, F., Mobbs, S., Neininger, B., Pal, S., Peters, G., Pigeon, G., Richard, E., Rotach, M., Russchenberg, H., Schwitalla, T., Smith, V., Steinacker, R., Trentmann, J., Turner, D., Van Baelen J., Vogt, S., Volkert, H., Weckwerth, T., Wernli, H., Wieser, A., and Wirth, M.: The convective and orographically-induced precipitation study (COPS): The scientific startegy, the field phase, and research highlights, Q. J. Roy. Meteorol. Soc., 137, 3-30, doi:10.1002/qj.752, 2011. 